\title{
Microwave Foaming of Materials: An Emerging Field
}

\author{
Mukarram Zubair ${ }^{1}\left(\mathbb{D}\right.$, Rebecca Ferrari ${ }^{2}{ }^{(0)}$, Omar Alagha ${ }^{1, *} \mathbb{C}^{\circ}$, Nuhu Dalhat Mu'azu ${ }^{1}(\mathbb{D}$, \\ Nawaf I. Blaisi ${ }^{1}$, Ijlal Shahrukh Ateeq ${ }^{3}{ }^{(D)}$ and Mohammad Saood Manzar ${ }^{1}$ (D) \\ 1 Department of Environmental Engineering, College of Engineering, Imam Abdulrahman Bin Faisal \\ University, P.O. Box 1982, Dammam 31451, Saudi Arabia; mzzubair@iau.edu.sa (M.Z.); \\ nmdalhat@iau.edu.sa (N.D.M.); niblaisi@iau.edu.sa (N.I.B.); msmanzar@iau.edu.sa (M.S.M.) \\ 2 Food, Water, Waste Research Group, Faculty of Engineering, University of Nottingham, University Park, \\ Nottingham NG7 2RD, UK; becca.ferrari@nottingham.ac.uk \\ 3 Department of Biomedical Engineering, College of Engineering, Imam Abdulrahman Bin Faisal University, \\ P.O. Box 1982, Dammam 31451, Saudi Arabia; Lsateeq@iau.edu.sa \\ * Correspondence: oaga@iau.edu.sa; Tel.: +966-13-333-1682
}

Received: 17 September 2020; Accepted: 22 October 2020; Published: 25 October 2020

\begin{abstract}
In the last two decades, the application of microwave heating to the processing of materials has to become increasingly widespread. Microwave-assisted foaming processes show promise for industrial commercialization due to the potential advantages that microwaves have shown compared to conventional methods. These include reducing process time, improved energy efficiency, solvent-free foaming, reduced processing steps, and improved product quality. However, the interaction of microwave energy with foaming materials, the effects of critical processing factors on microwave foaming behavior, and the foamed product's final properties are still not well-explored. This article reviews the mechanism and principles of microwave foaming of different materials. The article critically evaluates the impact of influential foaming parameters such as blowing agent, viscosity, precursor properties, microwave conditions, additives, and filler on the interaction of microwave, foaming material, physical (expansion, cellular structure, and density), mechanical, and thermal properties of the resultant foamed product. Finally, the key challenges and opportunities for developing industrial microwave foaming processes are identified, and areas for potential future research works are highlighted.
\end{abstract}

Keywords: foam; microwave heating; processing; polymer; biopolymer

\section{Introduction}

Foam materials exhibit a unique combination of properties that includes low density, low thermal conductivity, excellent insulation, and mechanical properties. The previous properties render them highly attractive materials for many industrial applications. Over the last two decades, foamed materials have been adopted in applications as diverse as packaging [1], automotive, building/construction [2], insulation and furniture, sports [3,4], environmental remediation [5,6], drug delivery, and tissue engineering $[7,8]$. Polymeric foams are the most commonly used foam materials, and are commercially termed "plastic foams". Bio-foams, another type of foam produced from bio-based materials, have received tremendous attention and show great industrial potential. Other materials besides these such as phenolic foams [9], metallic foams [10], and carbon foams [11] have been reported and are commercially used in the aerospace, construction [12], military [13], and supercapacitor [14] industries.

Conventionally, foamed materials are produced using processes that can be categorized as batch, injection, or extrusion processes. Process selection depends predominantly on the precursor raw materials, desired characteristics of the final product, and the target applications [15-17]. Batch processes are usually undertaken at a smaller scale to research and develop new materials or the study of foaming. 
At an industrial scale, injection and extrusion techniques are used within semi-batch and continuous processes to enable economically viable production $[18,19]$. Extrusion is the most widely used industrial technique for preparing polymeric foams due to its low cost [12]. However, studies have revealed that extrusion is not the most effective process for producing a well-controlled cellular structure in foams. This is due to poor porosity control; sometimes, there is a need for an additional processing step to remove accumulated solvent residues [20]. In order to overcome this issue, other foaming techniques such as modified supercritical fluids extrusion [11,14], freeze-drying/solvent exchange [9,21], and microwave-assisted foaming [22,23] have been investigated as routes to a uniform cellular structure as well as for better controlling the porosity of products. In recent decades, microwave processing has proved to be an attractive alternative heating method for materials processing. It has been effectively used for various applications from laboratory to industrial scales such as polymer processing [24], food processing [25], nanomaterial synthesis [26,27], foaming [28], pyrolysis [29], remediation of pollutants [30], and ore sorting [31]. Table 1 summarizes the main foaming methods used in the literature and their application for producing various types of foamed products. 
Table 1. A brief summary of methods used for the foaming of materials.

\begin{tabular}{|c|c|c|c|c|c|}
\hline Method & Steps & Application & Advantages & Disadvantages & References \\
\hline Extrusion & $\begin{array}{l}\text { - } \quad \text { Mixing of blowing agent in } \\
\text { a polymer matrix } \\
\text { - Nucleation at } \\
\text { high temperature } \\
\text { - Cell growth } \\
\text { - Cell stabilization }\end{array}$ & $\begin{array}{ll}\text { - } & \text { Petroleum polymer foams } \\
\text { (EPS, EPE, EPU), bio-foams } \\
\text { (PLA, starch, cellulose). }\end{array}$ & $\begin{array}{l}\text { - } \quad \text { Simple and continuous process } \\
\text { - } \quad \text { High production volume } \\
\text { - } \quad \text { Shorter times }(2-15 \mathrm{~min}) \\
\text { - } \quad \text { Foaming process economically feasible at a } \\
\text { - } \quad \text { Pre-molding is not needed } \\
\text { - Introduction of nucleating agents at any time }\end{array}$ & $\begin{array}{l}\text { - } \quad \text { Poor control of porosity, non-uniform } \\
\text { cellular structures } \\
\text { - } \quad \text { Presence of residues in the final product } \\
\text { - } \quad \text { High temperature and shear forces } \\
\text { - } \quad \text { cong single or double (usually } \\
\text { - } \quad \begin{array}{l}\text { Required tools expensive depending on } \\
\text { machine capacity }\end{array}\end{array}$ & {$[9,18]$} \\
\hline $\begin{array}{l}\text { Extrusion with } \\
\text { supercritical fluids }\end{array}$ & $\begin{array}{l}\text { - The solubility of the } \\
\text { physical blowing agent } \\
\left(\mathrm{CO}_{2}, \mathrm{~N}_{2}\right) \text { in the polymer } \\
\text { matrix at high pressure } \\
\text { - Creation of pores by } \\
\text { vaporization of } \\
\text { blowing agent. } \\
\text { - Stabilization of cell }\end{array}$ & $\begin{array}{l}\text { Petroleum polymer foams } \\
\text { (EPS, EPE, EPU), bio foams } \\
\text { (PLA, starch, cellulose). }\end{array}$ & $\begin{array}{l}\text { - } \quad \begin{array}{l}\text { Poor control of porosity, non-uniform } \\
\text { cellular structures. }\end{array} \\
\text { - } \quad \text { Presence of residues in the final product } \\
\text { - } \quad \text { High temperature and shear forces } \\
\text { - } \quad \text { cong single or double (usually } \\
\text { - Required tools expensive depending on } \\
\text { machine capacity }\end{array}$ & $\begin{array}{l}\text { - } \quad \text { High volatility of supercritical liquids } \\
\text { - } \quad \text { nuck of understanding of the } \\
\text { - } \quad \text { High diffusivity } \\
\text { - } \quad \text { Required single or double screws } \\
\quad \text { Required tools expensive depending on } \\
\text { machine capacity }\end{array}$ & {$[19,32]$} \\
\hline $\begin{array}{l}\text { Freeze-drying/solvent } \\
\text { exchange }\end{array}$ & $\begin{array}{ll}\text { - } & \text { Freezing } \\
\text { - } & \text { Primary drying } \\
\text { Secondary drying }\end{array}$ & $\begin{array}{l}\text { Bio-foams (starch, cellulose) } \\
\text { for tissue } \\
\text { engineering scaffolds }\end{array}$ & $\begin{array}{l}\text { - The cellular structure is controlled by the } \\
\text { - } \quad \text { Microfoams at a high freezing rate }\left(-196^{\circ} \mathrm{C}\right) \\
\text { and macro foams at a low freezing rate } \\
\left(-15^{\circ} \mathrm{C}\right) \\
\text { - Moderate density forms } 10^{4}-10^{11} \mathrm{cells} / \mathrm{cm}^{3}\end{array}$ & $\begin{array}{l}\text { - } \quad \text { Not applicable for all materials } \\
\text { - Low to moderate expansion }\end{array}$ & [19] \\
\hline Microwave foaming & $\begin{array}{ll}\text { - } & \text { Mixing of blowing agent } \\
\text { - } & \text { Microwave heating } \\
\text { - } & \text { Cell srowth } \\
& \end{array}$ & $\begin{array}{ll}\text { - } & \text { Bio-foams } \\
\text { - } & \text { Metallic foam } \\
& \text { Phenolic foam }\end{array}$ & $\begin{array}{ll}\text { - } & \text { Uniform heating } \\
\text { - } & \text { Fine cellular structure and greater cell sizes } \\
\text { - } & \text { Reduction of solvents }\end{array}$ & $\begin{array}{l}\text { Materials with good microwave absorption } \\
\text { can be foamed } \\
\text { High-density foam }\end{array}$ & {$[33,34]$} \\
\hline
\end{tabular}


Table 1. Cont.

\begin{tabular}{|c|c|c|c|c|c|}
\hline Method & Steps & Application & Advantages & Disadvantages & References \\
\hline Batch foaming & $\begin{array}{l}\text { - } \quad \text { Saturating polymer with a } \\
\text { blowing agent } \\
\text { - } \quad \text { Separation of the mixture } \\
\text { - } \quad \text { Cell nucleation } \\
\text { and stabilization } \\
\text { - Gradual foam } \\
\text { structure formation }\end{array}$ & $\begin{array}{ll}\text { - Thermoplastic } \\
\text { polymer foams }\end{array}$ & $\begin{array}{l}\text { - } \quad \text { Simple batch-wise process } \\
\text { - } \quad \text { Low material requirement } \\
\text { - } \quad \text { Pre-molding to the desired form } \\
\text { - } \quad \text { Achieve mativentials processing as no shear } \\
\text { - } \quad \text { Size distribution } \\
\text { - } \quad \text { Screw note to high expansion } \\
\text { Medium to high blowing agent uptake }\end{array}$ & $\begin{array}{l}\text { - } \quad \text { Limited to fundamental foam studies of } \\
\text { new materials } \\
\text { - Fixation of foaming composition } \\
\text { during pre-molding } \\
\text { - } \quad \text { Higher density } 106-1016 \text { cells } / \mathrm{cm}^{3} \text { compared } \\
\text { to batch and extrusion methods } \\
\text { - } \quad 30 \text { min to } 72 \mathrm{~h} \text { depending on polymer type } \\
\text { and sample thickness } \\
\text { - Pre-molding is needed }\end{array}$ & {$[18,19]$} \\
\hline $\begin{array}{l}\text { Injection molding } \\
\text { foaming }\end{array}$ & $\begin{array}{l}\text { - } \quad \text { Saturating polymer with a } \\
\text { blowing agent } \\
\text { - } \quad \text { Separation of the mixture } \\
\text { - } \quad \text { Cell nucleation } \\
\text { and stabilization } \\
\text { - Gradual foam } \\
\text { structure formation }\end{array}$ & $\begin{array}{ll}\text { - Thermoplastic } \\
\text { polymer foams }\end{array}$ & $\begin{array}{l}\text { - } \quad \text { Semi-continuous process } \\
\text { - } \quad \text { Complex foam parts formation } \\
\text { - } \quad \text { Cycle times shorter than the batch process } \\
\text { - The building of } 1 \text { to } 100 \text { microns uniform } \\
\text { cell diameters } \\
\text { - Introduction of nucleating agents at any time }\end{array}$ & $\begin{array}{l}\text { - } \quad \text { Pre-molding is not needed } \\
\text { A medium to a large number of materials (in } \\
\text { kilograms) is needed } \\
\text { - Supercritical fluid (SCF) as a physical } \\
\text { blowing agent. } \mathrm{CO}_{2} \text { and } \mathrm{N}_{2} \text { are usually used } \\
\text { as an agent } \\
\text { - } \quad \text { Expensive tools depend on machine capacity } \\
\text { - Mean cell size determination is difficult } \\
\text { Mechanisms of cell nucleation and growth } \\
\text { not understood }\end{array}$ & {$[18,19]$} \\
\hline
\end{tabular}


The benefits of microwave heating arise from its ability to provide volumetric heating of the bulk of the material and selective heating to particular phases with materials $[23,24]$. These benefits include easy on/off heating control and reduced processing time, faster healing rates, bulk penetration, which overcomes heat transfer limitations, the potential for lower energy consumption, and improved product quality compared to conventional heating $[35,36]$. The resulting process savings include reduced energy costs and lower product costs from higher throughputs [37].

Microwave processing has shown promise within the foaming industry. It has mainly been adopted for the fabrication of various kinds of foams such as plastic foams [38,39], starch foams [40], phenolic foams [38], and metallic foams [41]. Previous studies on microwave foaming methods highlighted its potential as a rapid and sustainable technique with little or zero dependence on blowing agents [42,43]. Moreover, the process has a high potential for the fabrication of both highand low-density foams $[9,44]$, controllable and even distribution of temperature resulting in a uniform cellular structure with low thermal conductivity foams $[15,45]$, and formation of highly porous scaffolds with excellent mechanical and thermal characteristics $[43,46,47]$. For instance, the compressive stress of temple and superfine flour foams produced via microwave foaming technique are 300 and $200 \mathrm{kPa}$, respectively, at 15\% strain. This was relatively higher than that of the EPS cushion block (180 kPa) and a wheat flour loose-fill foam $(20 \mathrm{kPa})$ [48].

Similarly, compressive strength wheat starch reinforced with straw fibers fabricated using microwave heating was $0.0065(\mathrm{MPa})$, which is relatively better than commercial biobased foam products [49-51]. These starch-based foams showed excellent mechanical and thermal stability at temperature ranges of $85^{\circ} \mathrm{C}$ to $95^{\circ} \mathrm{C}$ [46]. Microwave foaming has successfully produced cellular phenolic foams exhibiting low thermal conductivity of 0.029 to $0.064(\mathrm{~W} / \mathrm{mK})$ [15]. These values are comparable to commercial polyurethane (PU) foams of thermal conductivity of 0.022 and $0.035(\mathrm{~W} / \mathrm{m} \cdot \mathrm{K})$. Moreover, a high compressive strength of 1249-2170 (KPa) was also reported of phenolic foam reinforced with carbon by microwave foaming technique [52]. Recently, microwave-assisted chemical foaming and microwave hybrid heating have been reported to develop highly porous and thermally stable metallic foams that can be utilized as heat exchangers, catalyst substrates, and filters at elevated temperatures $[45,53,54]$. This has enabled the development of high-performance microwave-assisted foaming processes to produce materials for a diverse range of applications $[55,56]$.

The resulting characteristics of microwave-assisted foams-such as more uniform cellular structure, low density, conductivity, and mechanical and thermal stability-depends on key influential factors, namely microwave power (or power density), properties of precursor, blowing or nucleation agent, the addition of microwave absorbers (susceptors), moisture content, viscosity, and additives (salts, fiber, glass, etc.). In order to realize the benefits of microwave processing, the fundamental mechanisms involved during microwave foaming and their key controlling factors need to be better understood.

Although microwave processing is a growing area of research, reviews in this field have focused so far on the application of microwave heating in environmental engineering [51], food processing technologies [57], and chemical synthesis [58], with very few studies that focused only on the foaming materials [59-61] beside microwave heating [29,62]. Explicitly, there is no systematic review article on microwaves' application to foaming technology based on our detailed literature review. Therefore, this review article gives an in-depth description and mechanistic understanding of physical and chemical processes and steps involved during microwave foaming of different materials within the literature. The influence of critical microwave foaming parameters such as blowing agent, viscosity, microwave power, and exposure time, and reinforcing and nucleating agents on the behavior of final physical, mechanical, and thermal properties of foams are critically evaluated. Finally, the key challenges and opportunities for the development of industrial microwave foaming processes are identified, and a roadmap for potential future research works is defined. 


\section{Principle, Mechanism, and Steps in the Microwave Foaming}

In the last two decades, microwave foaming processes have been increasingly adopted for the production of starch-based foams [21], phenolic foams [11], EPS, and EPS-syntactic foams [23,63], and metallic foams [21,24]. This section will highlight the foaming steps and the mechanisms for producing foams using microwave heating. Table 2 summarizes the different microwave foaming processes with its physical, mechanical, and thermal characteristics of the resultant foamed products. The main advantage of microwave heating in foaming applications is that it heats the material volumetric, which is critical during expansion. Heat is generated by the interaction of polar molecules with the alternating microwave electromagnetic field. According to Fenghua Zhang and co-workers [13], this interaction continuously induces frictional loss due to polar molecules, converting electromagnetic energy into heat (Figure 1a). Therefore, compared to conventional heating, which is limited by heat transfer through the material's surface, microwaves can penetrate the materials causing uniform temperature distribution within the entire material, subject to penetration depth (Figure 1b).

In general, the microwave foaming processes involves three main steps: (i) Mixing of material with blowing agents. Water has been principally used as a blowing agent to produce polymeric foams, thermoset, and starch-based foams. This is because of its good microwave absorbing capacity. On the other hand, other blowing agents like sodium bicarbonate (SB), 4, 4-Oxybis (benzene sulfonyl-hydrazide (BSH), and azodicarbonamide (ADC), are also used for microwave foaming reaction. (ii) Nucleation or expansion of material during microwave irradiation. This is an important step that directly affects the cellular foam structure. The expansion of foam during microwave processing can be controlled by optimizing the microwave processing parameters, which are comprehensively discussed in Section 3. (iii) The stabilization of foam's cellular structure using drying or curing. The detailed description of microwave foaming steps of different materials is described in the following sections.
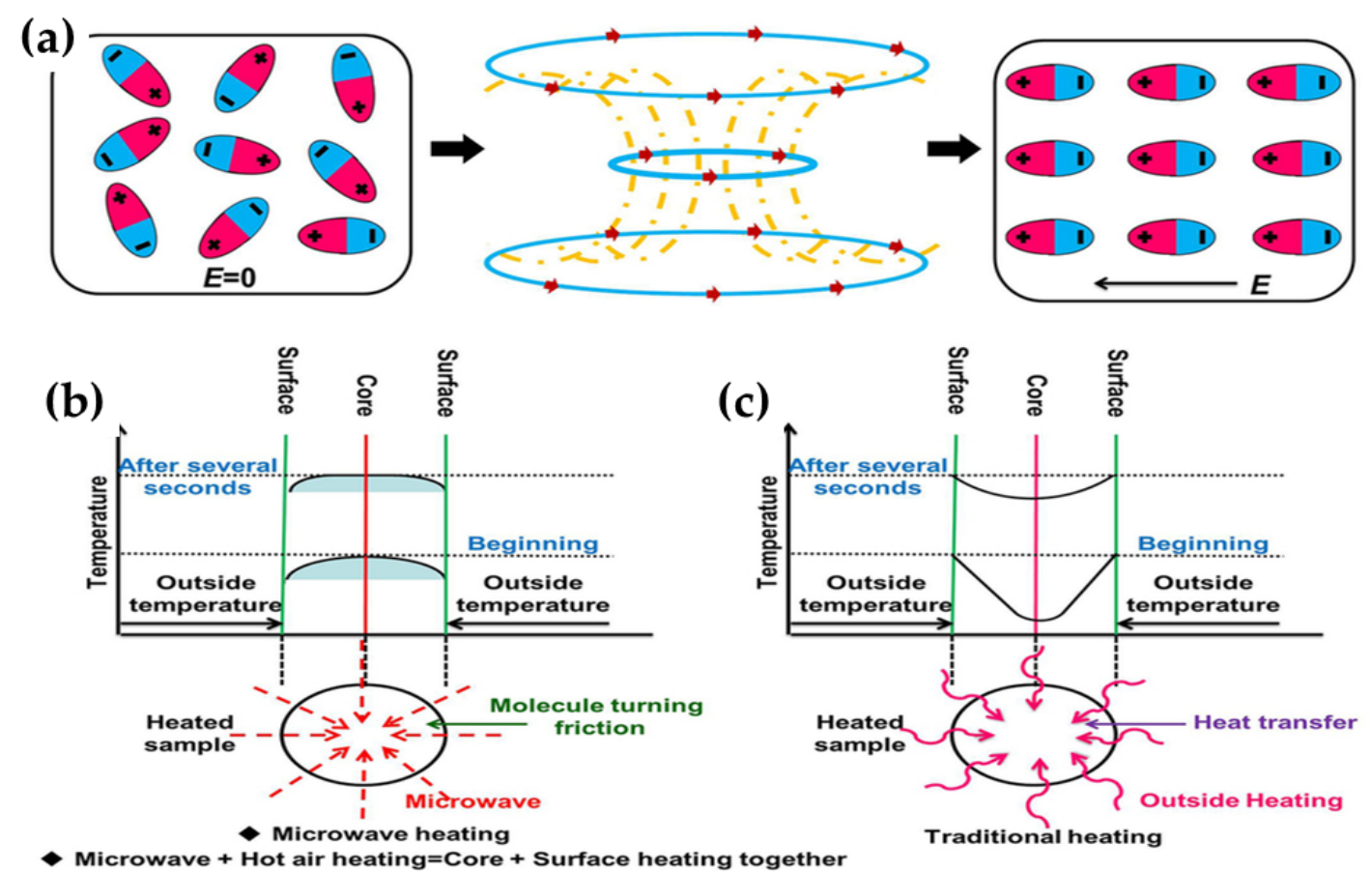

Figure 1. Mechanism of microwave heating (a,b), and traditional heating (c). Reprinted with permission from the authors of [13]. Copyright (C) (2015) Nature research. 
Table 2. Summary of microwave foaming process and characteristics of foamed products.

\begin{tabular}{|c|c|c|c|c|c|c|c|c|c|c|c|}
\hline \multirow[b]{2}{*}{ Precursor } & \multirow[b]{2}{*}{$\begin{array}{l}\text { Blowing } \\
\text { Agent }\end{array}$} & \multirow[b]{2}{*}{ Additives } & \multicolumn{2}{|c|}{ Operating Condition } & \multirow[b]{2}{*}{$\begin{array}{l}\text { Foaming } \\
\text { Steps }\end{array}$} & \multicolumn{4}{|c|}{ Foam Product Properties } & \multirow[b]{2}{*}{ Remarks/Microwave Benefits } & \multirow[b]{2}{*}{ Reference } \\
\hline & & & $\begin{array}{l}\text { Power } \\
\text { (Watt) }\end{array}$ & Time (s) & & Product & Density $\left(\mathrm{g} / \mathrm{cm}^{3}\right)$ & Porosity & $\begin{array}{l}\text { Compressive Strength } \\
\text { (MPa)/Thermal } \\
\text { Conductivity (W/m K) }\end{array}$ & & \\
\hline $\begin{array}{l}\text { Temple flour, superfine } \\
\text { flour, purified wheat } \\
\text { starch }\end{array}$ & Hydrocerol & $\begin{array}{l}\text { Calcium chloride } \\
\text { and sodium } \\
\text { chloride, talc } \\
\text { powder }\end{array}$ & - & $50-65$ & $\begin{array}{l}\text { Extrusion } \\
(12 \%-13 \% \\
\text { MC) } \\
\text { Additive } \\
\text { addition } \\
\text { Microwave } \\
\text { foaming }\end{array}$ & $\begin{array}{l}\text { Temple } \\
\text { Superfine } \\
\text { Starch } \\
\text { Temple/NaCl } \\
\text { Temple/CaCl } \\
\text { Temple/BIH } \\
\text { Temple/talc } \\
(2.2 \%)\end{array}$ & $\begin{array}{l}0.15 \\
0.114 \\
0.139 \\
0.095 \\
0.092 \\
0.144 \\
0.188\end{array}$ & & $\begin{array}{l}0.314 /- \\
0.180 /- \\
0.161 /- \\
0.250 /- \\
0.174 /- \\
0.334 /- \\
0.489 /-\end{array}$ & $\begin{array}{l}\text { Effective microwave absorption due } \\
\text { to the presence of salts led to the } \\
\text { increase in heating rate, low } \\
\text { moisture loss due to diffusion, and } \\
\text { larger cell sizes. } \\
\text { The mechanical properties of } \\
\text { microwave foamed foam were } \\
\text { found close to that of the EPS block. }\end{array}$ & [48] \\
\hline $\begin{array}{l}\text { Purified wheat starch } \\
\text { wheat flour }\end{array}$ & Water & $\begin{array}{l}\text { Glycerol, } \\
\text { polyvinyl } \\
\text { alcohol }\end{array}$ & & & $\begin{array}{l}\text { Extrusion } \\
\text { and addition } \\
\text { of additives } \\
\text { Microwave } \\
\text { foaming }\end{array}$ & - & - & - & & $\begin{array}{l}\text { Glycerol enhanced microwave } \\
\text { absorption efficiency and high } \\
\text { heating rate at lower microwave } \\
\text { power } \\
\text { Presence of additives constraint to } \\
\text { foam cell growth during microwave } \\
\text { foaming }\end{array}$ & [64] \\
\hline $\begin{array}{l}\text { Purified wheat starch } \\
\text { wheat flour }\end{array}$ & Water & $\begin{array}{l}\text { Glycerol, } \\
\text { polyvinyl } \\
\text { alcohol }\end{array}$ & 200 & & & - & - & - & & $\begin{array}{l}\text { Reduction in expansion during } \\
\text { microwave foaming of starch } \\
\text { materials containing glycerol }\end{array}$ & [46] \\
\hline Native corn starch & Water & None & $\begin{array}{l}400 \\
600 \\
800\end{array}$ & $\begin{array}{l}120 \\
120 \\
120\end{array}$ & $\begin{array}{l}\text { Extrusion } \\
\text { (MC 41\%) } \\
\text { Vacuum } \\
\text { foaming and } \\
\text { drying }\end{array}$ & & & $\begin{array}{l}2020 \text { pores } \\
1018 \text { pores } \\
1970 \text { pores }\end{array}$ & & $\begin{array}{l}\text { Higher the microwave power leads } \\
\text { to a higher number of vapor } \\
\text { bubbles nucleated and showed } \\
\text { increase in the volume expansion } \\
\text { microwave Vacuum expansion } \\
\text { allows an indirect expansion with } \\
\text { lower time and energy consumption }\end{array}$ & [65] \\
\hline Native corn starch & Water & None & $\begin{array}{l}400 \\
600 \\
800\end{array}$ & $\begin{array}{l}120 \\
120 \\
120\end{array}$ & $\begin{array}{l}\text { Extrusion } \\
\text { (MC } 0.695 \\
\mathrm{~kg} / \mathrm{kg} \text { ) } \\
\text { Vacuum } \\
\text { foaming and } \\
\text { drying }\end{array}$ & & $\begin{array}{l}0.82 \mathrm{EI} \\
0.97 \mathrm{EI} \\
1.17 \mathrm{EI}\end{array}$ & & & $\begin{array}{l}\text { The volume of starch-based pellets } \\
\text { significantly increased } \\
\text { with increasing microwave power; } \\
\text { effective moisture diffusivities } \\
\text { increased with an increasing } \\
\text { microwave power. }\end{array}$ & [66] \\
\hline Native wheat starch & Water & $\begin{array}{l}\text { Barley } \\
\text { straw fibers, } \\
\text { cardoon waste, } \\
\text { and grape waste. } \\
\text { Barley straw } \\
\text { fibers }\end{array}$ & 900 & 50 & $\begin{array}{l}\text { Extrusion } \\
\text { with and } \\
\text { without } \\
\text { additives } \\
\text { Microwave } \\
\text { foaming of } \\
\text { sheets in } \\
\text { PTFE mold }\end{array}$ & $\begin{array}{l}\text { Starch } \\
\text { Starch/Barley } \\
(95: 5) \\
\text { Starch/Grape } \\
(95: 5) \\
\text { Starch } \\
\text { Cardoon (95:5) }\end{array}$ & $\begin{array}{l}0.292 \\
0.347 \\
0.301 \\
0.303\end{array}$ & $\begin{array}{l}\text { cell sizes > } \\
0.5\end{array}$ & $\begin{array}{l}0.87 /- \\
2.18 /- \\
2.03 /- \\
1.92 /-\end{array}$ & $\begin{array}{l}\text { The microwave foaming process } \\
\text { allowed the continuous production } \\
\text { of foam blocks (without joining } \\
\text { between pellets). This leads to } \\
\text { about an } 800 \text {-time increase in } \\
\text { mechanical performance (stiffness } \\
\text { and strength) compared to pellets } \\
\text { microwave foaming. }\end{array}$ & [51] \\
\hline Maize flour & & $\begin{array}{l}\text { Zein } \\
\text { biopolymers }\end{array}$ & 1000 & 15 & $\begin{array}{l}\text { Extrusion } \\
\text { with and } \\
\text { without } \\
\text { additives } \\
\text { (MC 26\%) } \\
\text { Microwave } \\
\text { foaming }\end{array}$ & $\begin{array}{l}\text { Starch } \\
\text { Starch/zein/55/5 } \\
\text { Starch/zein/85/15 } \\
\text { Starch/zein/70/30 }\end{array}$ & $\begin{array}{l}0.16 \\
0.2 \\
0.22 \\
0.44\end{array}$ & $\begin{array}{l}<100 \mathrm{um} \\
<100 \mathrm{um} \\
<100 \mathrm{um} \\
>200 \mathrm{um}\end{array}$ & & $\begin{array}{l}\text { Foams from microwaved polymer } \\
\text { mixture exhibited finer cellular } \\
\text { structure compared to directly } \\
\text { expanded material. }\end{array}$ & [67] \\
\hline
\end{tabular}


Table 2. Cont.

\begin{tabular}{|c|c|c|c|c|c|c|c|c|c|c|c|}
\hline \multirow[b]{2}{*}{ Precursor } & \multirow[b]{2}{*}{$\begin{array}{c}\text { Blowing } \\
\text { Agent }\end{array}$} & \multirow[b]{2}{*}{ Additives } & \multicolumn{2}{|c|}{ Operating Condition } & \multirow[b]{2}{*}{$\begin{array}{c}\text { Foaming } \\
\text { Steps }\end{array}$} & \multicolumn{4}{|c|}{ Foam Product Properties } & \multirow[b]{2}{*}{ Remarks/Microwave Benefits } & \multirow[b]{2}{*}{ Reference } \\
\hline & & & $\begin{array}{l}\text { Power } \\
\text { (Watt) }\end{array}$ & Time (s) & & Product & Density $\left(\mathrm{g} / \mathrm{cm}^{3}\right)$ & Porosity & $\begin{array}{l}\text { Compressive Strength } \\
\text { (MPa)/Thermal } \\
\text { Conductivity (W/m K) }\end{array}$ & & \\
\hline Carboxymethylcellulose & Pluronic & $\begin{array}{l}\text { Polyethylene } \\
\text { glycol diacrylate }\end{array}$ & 900 & 105 & $\begin{array}{l}\text { Mixing of } \\
\text { polymers } \\
\text { and blowing } \\
\text { agent } \\
\text { Microwave } \\
\text { foaming } \\
\text { Drying }\end{array}$ & & & & & $\begin{array}{l}\text { The microwave method effectively } \\
\text { induced thermo-polymerization } \\
\text { with time and energy savings. The } \\
\text { foam is a hierarchical structure } \\
\text { having open porosity of different } \\
\text { sizes. }\end{array}$ & [57] \\
\hline Resole & Air bubbles & - & 12,000 & $3-20$ & $\begin{array}{l}\text { Mixing of } \\
\text { resoling, } \\
\text { hardener, } \\
\text { and air } \\
\text { bubbles } \\
\text { using an } \\
\text { impeller } \\
\text { Microwave } \\
\text { foaming }\end{array}$ & Phenolic foam & 0.12 & $\begin{array}{l}\text { 100-150 um } \\
\text { dia }\end{array}$ & $-/ 0.029$ & $\begin{array}{l}\text { Microwave significantly decreased } \\
\text { the content of } \mathrm{H}_{2} \mathrm{O} \text { (the byproduct } \\
\text { of cure reaction), which leads to low } \\
\text { conductivity foams compared to } \\
\text { conventional phenolic foams. }\end{array}$ & [15] \\
\hline $\begin{array}{l}\text { Resole-type } \\
\text { phenolic resins }\end{array}$ & Air bubbles & AC powder & 12,000 & & $\begin{array}{l}\text { Mixing the } \\
\text { resole and } \\
\text { accelerators } \\
\text { with or } \\
\text { without } \\
\text { the AC using } \\
\text { an impeller } \\
\text { chemical } \\
\text { cure reaction } \\
\text { Microwave } \\
\text { foaming }\end{array}$ & $\begin{array}{l}\text { Phenolic foam } \\
\text { Phenolic/AC } \\
\text { (1 wt } \%)\end{array}$ & $\begin{array}{l}0.127 \\
0.103\end{array}$ & $\begin{array}{l}233.8 \mathrm{um} \\
169.6 \mathrm{um}\end{array}$ & $\begin{array}{l}1.68 / 0.064 \\
2.17 /-0.071\end{array}$ & $\begin{array}{l}\text { Microwave radiation helps } \\
\text { chemical interaction between the } \\
\text { phenolic resin and AC during } \\
\text { foaming that induces a robust } \\
\text { interface and thus resulted in a } \\
\text { firmer foam. }\end{array}$ & [52] \\
\hline $\begin{array}{l}\text { Resole-type } \\
\text { phenolic resins }\end{array}$ & Air bubbles & $\begin{array}{l}\text { MWCNT and } \\
\text { graphene }\end{array}$ & 12,000 & 20 & $\begin{array}{l}\text { Mixing the } \\
\text { resole and } \\
\text { accelerators } \\
\text { with or } \\
\text { without } \\
\text { the additives } \\
\text { using an } \\
\text { impeller } \\
\text { chemical } \\
\text { cure reaction } \\
\text { Microwave } \\
\text { foaming }\end{array}$ & $\begin{array}{l}\text { Phenolic foam } \\
0.5 \mathrm{wt} \% \\
\text { MWCNT } \\
1.0 \mathrm{wt} \% \\
\text { MWCNT } \\
0.5 \mathrm{wt} \% \\
\text { Graphen } \\
1.0 \mathrm{wt} \% \\
\text { Graphene }\end{array}$ & $\begin{array}{l}0.065 \\
0.050 \\
0.065 \\
0.072 \\
0.048\end{array}$ & $\begin{array}{l}94.4 \% \\
95.3 \% \\
93.8 \% \\
93.5 \% \\
95.4 \%\end{array}$ & $\begin{array}{l}0.11 /- \\
0.14 /- \\
0.13 /- \\
0.14 /- \\
0.17 /-\end{array}$ & $\begin{array}{l}\text { The cure starting point of the } \\
\text { particle-reinforced phenolic } \\
\text { resin occurred sooner than that of } \\
\text { the neat phenolic resin } \\
\text { because nanoparticles catalyze the } \\
\text { cure reaction of the phenolic } \\
\text { resin at lower temperatures due to } \\
\text { microwaves. }\end{array}$ & [68] \\
\hline $\begin{array}{l}\text { Resole-type } \\
\text { phenolic resin }\end{array}$ & Air bubbles & $\begin{array}{l}\text { Chopped glass } \\
\text { fiber, ethanol, } \\
\text { PTSA catalyst }\end{array}$ & 1000 & 60 & $\begin{array}{l}\text { Resin } \\
\text { preparation } \\
\text { and air } \\
\text { bubbles } \\
\text { entrapping } \\
\text { Acid catalyst } \\
\text { mixing } \\
\text { Foaming } \\
\text { and curing }\end{array}$ & $\begin{array}{l}\text { Phenolic foam } \\
\text { with } 12 \% \\
\text { ethanol and } 3 \\
\text { or } 6 \mathrm{wt} \% \\
\text { catalyst }\end{array}$ & 0.035 & & $0.148 / 0.039$ & $\begin{array}{l}\text { Highly uniform phenolic foam was } \\
\text { fabricated with } 12 \mathrm{wt} \% \text { ethanol } \\
\text { using closed mold microwave } \\
\text { foaming process. }\end{array}$ & [47] \\
\hline
\end{tabular}


Table 2. Cont.

\begin{tabular}{|c|c|c|c|c|c|c|c|c|c|c|c|}
\hline \multirow[b]{2}{*}{ Precursor } & \multirow[b]{2}{*}{$\begin{array}{c}\text { Blowing } \\
\text { Agent }\end{array}$} & \multirow[b]{2}{*}{ Additives } & \multicolumn{2}{|c|}{ Operating Condition } & \multirow[b]{2}{*}{$\begin{array}{c}\text { Foaming } \\
\text { Steps }\end{array}$} & \multicolumn{4}{|c|}{ Foam Product Properties } & \multirow[b]{2}{*}{ Remarks/Microwave Benefits } & \multirow[b]{2}{*}{ Reference } \\
\hline & & & $\begin{array}{l}\text { Power } \\
\text { (Watt) }\end{array}$ & Time (s) & & Product & Density $\left(\mathrm{g} / \mathrm{cm}^{3}\right)$ & Porosity & $\begin{array}{l}\text { Compressive Strength } \\
\text { (MPa)/Thermal } \\
\text { Conductivity (W/m K) }\end{array}$ & & \\
\hline BA & ss & & 900 & 240 & $\begin{array}{l}\text { Missing of } \\
\text { BA and SS } \\
\text { Microwave } \\
\text { foaming in } \\
\text { Teflon mold } \\
\text { Removal of } \\
\text { moisture } \\
\text { content }\end{array}$ & $\begin{array}{l}\text { BA:SS(4:6) } \\
\text { BA:SS(5:5) } \\
\text { BAASS(6:4) } \\
\text { BA:SS(7:3) }\end{array}$ & $\begin{array}{l}0.61 \\
0.64 \\
1.1 \\
1.3\end{array}$ & $\begin{array}{l}72.64 \% \\
71.3 \% \\
50.67 \% \\
41.7 \%\end{array}$ & $\begin{array}{l}3.55 / 0.075 \\
3 / 0.07 \\
6.23 / 0.09 \\
3.67 / 0.091\end{array}$ & $\begin{array}{l}\text { Microwave heating initiates the } \\
\text { cross-linking of silicates groups, } \\
\text { which form an impermeable skin } \\
\text { and leads to a highly porous } \\
\text { scaffold during foaming. }\end{array}$ & [60] \\
\hline TPUR & $\mathrm{ADC}$ & СВ & 500 & 180 ( 4 cycles $)$ & $\begin{array}{l}\text { Extrusion } \\
\text { with } \\
\text { blowing } \\
\text { agent and } \\
\text { CB } \\
\text { Microwave } \\
\text { foaming }\end{array}$ & $\begin{array}{l}\text { TPUR + ADC } \\
\text { TPUR + ADC } \\
+\mathrm{CB}\end{array}$ & $\begin{array}{l}0.564 \\
0.050\end{array}$ & $\begin{array}{l}- \\
-\end{array}$ & & $\begin{array}{l}\text { The presence of CB in TPUR } \\
\text { showed effective microwave } \\
\text { heating due to an increase in } \\
\text { microwave absorbance, which gave } \\
\text { more fine particles. } \\
\text { Carbon black additive improves the } \\
\text { cell structure and, increases the } \\
\text { apparent density but significantly } \\
\text { worsens its mechanical properties. }\end{array}$ & [69] \\
\hline EPS & $\begin{array}{l}\text { Ethanol, } \\
\text { hydrogen } \\
\text { peroxide, } \\
\text { ethanol/water }\end{array}$ & - & 950 & 180 & $\begin{array}{l}\text { Injection of } \\
\text { solvents in } \\
\text { EPS beads } \\
\text { Microwave } \\
\text { foaming }\end{array}$ & - & - & - & -10.029 & $\begin{array}{l}\text { The better temperature distribution } \\
\text { was achieved with hydrogen } \\
\text { peroxides using microwave heating. }\end{array}$ & [43] \\
\hline Epoxy resin and EPS & & Hardener & 950 & - & $\begin{array}{l}\text { Mixing of } \\
\text { epoxy resin } \\
\text { hardener } \\
\text { and EPS } \\
\text { beads } \\
\text { Microwave } \\
\text { foaming } \\
\text { Curing }\end{array}$ & $\begin{array}{l}\text { EPS-Epoxy 5\% } \\
(w / w) \\
\text { EPS-Epoxy } \\
45 \%(w / w)\end{array}$ & $\begin{array}{l}0.84 \\
0.28\end{array}$ & - & & $\begin{array}{l}\text { The microwave foaming process } \\
\text { successfully molded the syntactic } \\
\text { foam with sophisticated geometry } \\
\text { and smooth surfaces. }\end{array}$ & [70] \\
\hline $\begin{array}{l}\text { Unexpanded EPS } \\
\text { microspheres }\end{array}$ & Pentane & Phenolic resin & 1000 & & $\begin{array}{l}\text { Mixing of } \\
\text { EPS, } \\
\text { pentane, and } \\
\text { phenolic } \\
\text { resin } \\
\text { Microwave } \\
\text { foaming } \\
\text { Post curing }\end{array}$ & $\begin{array}{l}\text { Neat EPS foam } \\
\text { Composite } \\
\text { EPS foam }\end{array}$ & $\begin{array}{l}0.043 \\
0.093\end{array}$ & & $\begin{array}{l}3.35 /- \\
5.80 /-\end{array}$ & $\begin{array}{l}\text { Effective expansion of EPS-syntactic } \\
\text { foam at high EPS loading via } \\
\text { microwave heating } \\
\text { Improved fire-resistant properties } \\
\text { due to the formation of a } \\
\text { honeycomb structure of composite } \\
\text { foam compared to neat polystyrene } \\
\text { foam. }\end{array}$ & [44] \\
\hline EPDM, PP & $\mathrm{ADC}$ & $\begin{array}{l}\text { Urea, } \\
\text { paraformaldehyde, } \\
\text { iron oxide }\end{array}$ & 900 & 720 & $\begin{array}{l}\text { The } \\
\text { blending of } \\
\text { all materials } \\
\text { preparation } \\
\text { of } \\
\text { microcapsules } \\
\text { microwave } \\
\text { irradiation }\end{array}$ & EPDM/PP & 0.61 & - & & $\begin{array}{l}\text { The microwave technique allows } \\
\text { the production of EPDM/PP foam } \\
\text { with uniform voids and greater cell } \\
\text { sizes of } 435 \text { microns, which is } \\
\text { almost double produced using the } \\
\text { conventional technique. }\end{array}$ & [61] \\
\hline
\end{tabular}


Table 2. Cont.

\begin{tabular}{|c|c|c|c|c|c|c|c|c|c|c|c|}
\hline \multirow[b]{2}{*}{ Precursor } & \multirow[b]{2}{*}{$\begin{array}{c}\text { Blowing } \\
\text { Agent }\end{array}$} & \multirow[b]{2}{*}{ Additives } & \multicolumn{2}{|c|}{ Operating Condition } & \multirow[b]{2}{*}{$\begin{array}{l}\text { Foaming } \\
\text { Steps }\end{array}$} & \multicolumn{4}{|c|}{ Foam Product Properties } & \multirow[b]{2}{*}{ Remarks/Microwave Benefits } & \multirow[b]{2}{*}{ Reference } \\
\hline & & & $\begin{array}{l}\text { Power } \\
\text { (Watt) }\end{array}$ & Time (s) & & Product & Density $\left(\mathrm{g} / \mathrm{cm}^{3}\right)$ & Porosity & $\begin{array}{l}\text { Compressive Strength } \\
\text { (MPa)/Thermal } \\
\text { Conductivity (W/m K) }\end{array}$ & & \\
\hline CS, PEGDA & Pluronic & - & $800-1000$ & $45-240$ & $\begin{array}{l}\text { Mixing of } \\
\text { materials } \\
\text { and foaming } \\
\text { agent } \\
\text { Microwave } \\
\text { heating } \\
\end{array}$ & $\begin{array}{l}\text { 30P70CS1.5 } \\
\text { 40P60CS1.5 }\end{array}$ & & $\begin{array}{l}78.90 \\
60.76\end{array}$ & & $\begin{array}{l}\text { Microwave heating allows a } \\
\text { homogenous heating process and } \\
\text { effectively produced a highly } \\
\text { porous interconnected scaffold. }\end{array}$ & [71] \\
\hline $\begin{array}{l}\text { Titanium and } \\
\text { aluminum }\end{array}$ & & $\begin{array}{l}\text { Boron carbide } \\
\left(\mathrm{B}_{4} \mathrm{C}\right)\end{array}$ & $200-450$ & & $\begin{array}{l}\text { A blending } \\
\text { of } \\
\text { aluminum, } \\
\text { titanium and } \\
\text { B4C } \\
\text { uniaxial } \\
\text { pressing to } \\
\text { make a } \\
\text { cylindrical } \\
\text { precursor } \\
\text { microwave } \\
\text { heating }\end{array}$ & $\begin{array}{l}\mathrm{Al}_{3} \mathrm{Ti} \\
\mathrm{Al}_{3} \mathrm{Ti}+10 \% \\
\mathrm{~B}_{4} \mathrm{C} \\
\mathrm{Al}_{3} \mathrm{Ti}+10 \% \\
\mathrm{~B}_{4} \mathrm{C}\end{array}$ & - & $\begin{array}{l}40 \% \\
60 \% \\
61 \%\end{array}$ & & $\begin{array}{l}\text { Microwave heating succeeded in } \\
\text { ignition combustion synthesis } \\
\text { reaction to produce Al3Ti foam. }\end{array}$ & [72] \\
\hline Nickel nitrate & - & Glycine & 1000 & 60 & $\begin{array}{l}\text { Mixing } \\
\text { glycine with } \\
\text { a nitrate } \\
\text { solution } \\
\text { Microwave } \\
\text { foaming }\end{array}$ & Nickel foam & - & $40 \%$ & & $\begin{array}{l}\text { Microwave showed high potential } \\
\text { to provide a homogenous and } \\
\text { increased impregnation rate in the } \\
\text { porous scaffold with no surface } \\
\text { structure damage. } \\
\text { The nanoparticle-microwave } \\
\text { interaction caused interconnected } \\
\text { nanoparticles, resulting in a } \\
\text { percolating network inside the } \\
\text { scaffold. }\end{array}$ & [73] \\
\hline $\begin{array}{l}\text { Graphitic carbon foam } \\
\text { (70\% porosity) }\end{array}$ & & $\begin{array}{l}\text { Boric acid } \\
\text { and urea }\end{array}$ & 400 & $300-18,00$ & $\begin{array}{l}\text { Microwave } \\
\text { heating of } \\
\text { carbon foam } \\
\text { in the } \\
\text { presence of } \\
\text { additives } \\
\text { Vacuum } \\
\text { drying } \\
\text { Annealing at } \\
\text { 500-1100 }{ }^{\circ} \mathrm{C} \\
\end{array}$ & $\begin{array}{l}\text { Boron carbon } \\
\text { nitride foam }\end{array}$ & & & & $\begin{array}{l}\text { Microwave treatment effectively } \\
\text { activated surface chemical reactions } \\
\text { between carbon foam, boric acid, } \\
\text { and urea. }\end{array}$ & [74] \\
\hline Sucrose & Water & Silica gel & 850 & 180 & $\begin{array}{l}\text { Mixing of } \\
\text { sucrose, } \\
\text { silica gel, } \\
\text { and water } \\
\text { Microwave } \\
\text { irradiation } \\
\text { thermal } \\
\text { treatment at } \\
800^{\circ} \mathrm{C} \text { under } \\
\text { nitrogen } \\
\text { atmosphere }\end{array}$ & Carbon foam & 0.17 & $\begin{array}{l}97 \% \\
(5-6 \mathrm{~nm})\end{array}$ & & $\begin{array}{l}\text { Highly porous carbon/silica foam } \\
\text { produced using microwave without } \\
\text { any blowing agent. }\end{array}$ & [59] \\
\hline
\end{tabular}


Table 2. Cont

\begin{tabular}{|c|c|c|c|c|c|c|c|c|c|c|c|}
\hline \multirow[b]{2}{*}{ Precursor } & \multirow[b]{2}{*}{$\begin{array}{l}\text { Blowing } \\
\text { Agent }\end{array}$} & \multirow[b]{2}{*}{ Additives } & \multicolumn{2}{|c|}{ Operating Condition } & \multirow[b]{2}{*}{$\begin{array}{l}\text { Foaming } \\
\text { Steps }\end{array}$} & \multicolumn{4}{|c|}{ Foam Product Properties } & \multirow[b]{2}{*}{ Remarks/Microwave Benefits } & \multirow[b]{2}{*}{ Reference: } \\
\hline & & & $\begin{array}{l}\text { Power } \\
\text { (Watt) }\end{array}$ & Time (s) & & Product & Density $\left(\mathrm{g} / \mathrm{cm}^{3}\right)$ & Porosity & $\begin{array}{c}\text { Compressive Strength } \\
\text { (MPa)/Thermal } \\
\text { Conductivity (W/m K) }\end{array}$ & & \\
\hline PCL & DCM & ВРO & 700 & 240 & $\begin{array}{l}\text { Dissolve } \\
\text { PCL in DCM } \\
\text { with BPO } \\
\text { and mix to } \\
\text { homogenous } \\
\text { Microwave } \\
\text { foaming }\end{array}$ & $\begin{array}{l}\text { PCL-10 wt } \% \\
\text { BPOPCL-15 } \\
\text { wt } \% \text { BPO }\end{array}$ & $\begin{array}{l}0.40 \\
0.37\end{array}$ & $\begin{array}{l}63.55 \% \\
66.39 \%\end{array}$ & & $\begin{array}{l}\text { The microwave heating } \\
\text { considerably increased the } \\
\text { actuation efficiency compared to } \\
\text { other heating methods. }\end{array}$ & [13] \\
\hline Mimosa tannin extract & $\begin{array}{l}\text { Water, } \\
\text { furfuryl } \\
\text { alcohol, } \\
\text { methanol } \\
\text { diethylether }\end{array}$ & - & 600 & 120 & $\begin{array}{l}\text { Mixing of all } \\
\text { solvent and } \\
\text { tannin } \\
\text { extract } \\
\text { Microwave } \\
\text { foaming }\end{array}$ & $\begin{array}{l}\text { tannin-furanic } \\
\text { foams }\end{array}$ & 0.11 & & $0.44 /-$ & $\begin{array}{l}\text { The microwave foaming method of } \\
\text { tannic-furanic foam allows a } \\
\text { substantially reduced hardening } \\
\text { rate of the polymer and the } \\
\text { solvent's blowing. } \\
\text { This facilitates faster } \\
\text { polymerization and water } \\
\text { evaporation and decreased the } \\
\text { blowing agent consumption. }\end{array}$ & [75] \\
\hline
\end{tabular}




\subsection{Starch-Based Foams}

Starch-based foams are produced by microwave processing by using either plasticized starch (processed through extrusion) $[9,15]$ or starch-containing water batter (which eliminates the production step of extrusion) [27]. The microwave expansion can be performed in either a PTFE cavity to create a molded part or free expansion. Figure 2 shows the fabrication steps of starch foam via microwave foaming of extruded plasticized starch as reported by Moraru and Kokini [70]; the actual microwave foaming mechanism of starchy matrix progress is as follows. Initially, the applied microwave energy selectively heats the water, increasing the temperature of the matrix volumetrically. As the temperature rapidly increases, the water generates homogenous superheated steam, which serves as a driving force that creates high pressure inside the starchy matrix. Afterward, the matrix starts to expand (nucleate) under superheated pressure due to its transition from a glassy state to a rubbery state. The nucleation and bubble growth during microwave foaming are the key steps to attain the required characteristics of foams. Their behavior depends on the factors discussed in the section below. According to Moraru and Kokini [76] and Shafi et al. [74], bubble growth is directly related to the foams' pore structure and pore distribution. The formation of vapor bubbles is derived by superheated steam pressure inside the matrix, which is controlled by surface temperature and moisture content of the matrix [45]. S. Kraus et al. [64] reported that increasing microwave power leads to faster removal of water during the foaming process that, in turn, increases the number of vapor bubbles and decreases the pore size of the product. This finally results in more expansion of matrix compared to low microwave powers. In addition, during bubble growth, significant water loss occurs due to the escape of water vapor through the bursting or thinning of cell walls. This transforms the polymer matrix into a glassy state, stabilizing the cell structure [46].

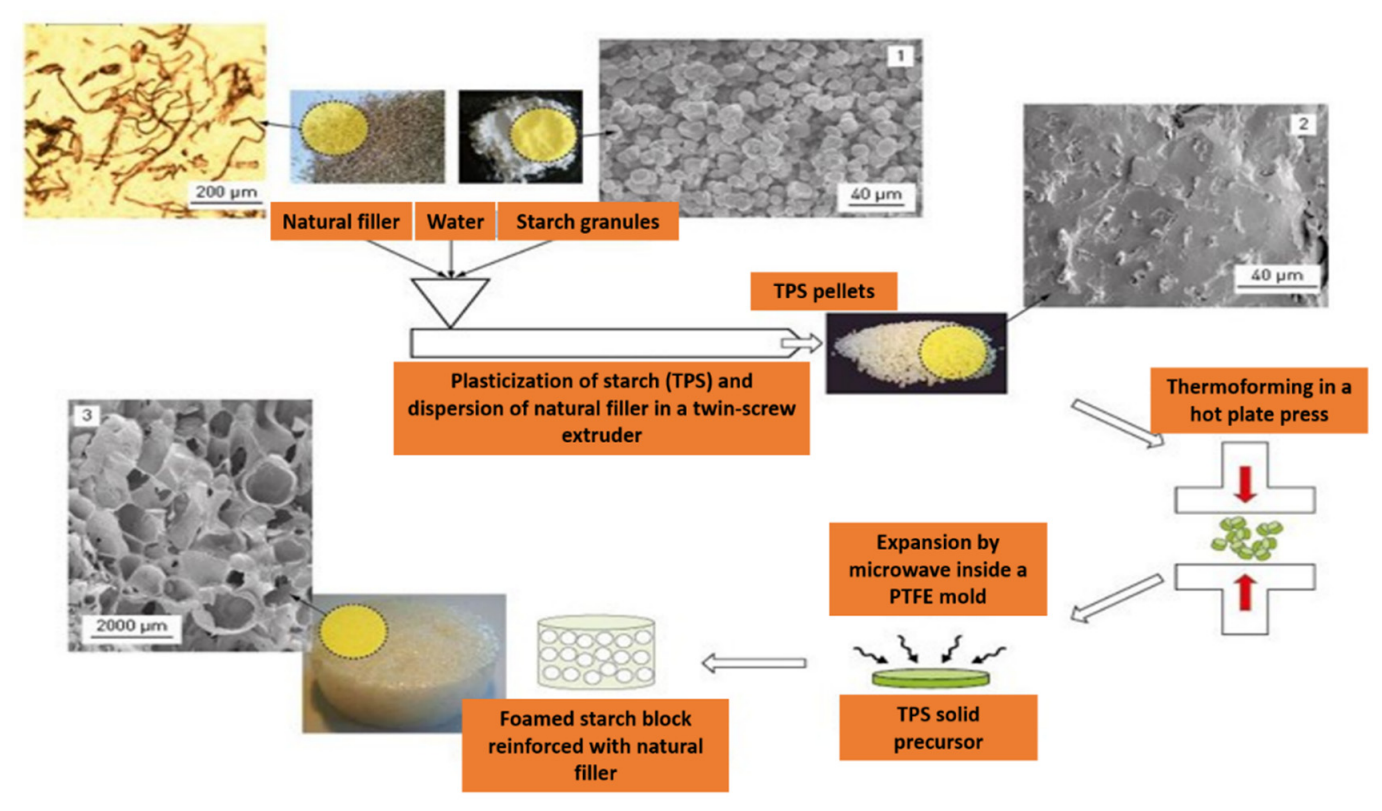

Figure 2. Microwave foaming process of starch foam from extruded plasticized starch [77].

\subsection{Polystyrene and Syntactic Foams}

The highly efficient and fast manufacturing of polystyrene foams revealed microwaves as a promising potential technique in the polystyrene industry. Calles-Arriaga et al. [43] formed polystyrene foams using microwave heating of EPS microspheres with three different solvents (ethanol, ethanol/water, and hydrogen peroxide). Similarly, the production of syntactic foams with EPS microspheres was also studied using microwaves [44,70,78]. Usually, solvents with high dielectric loss (such as water) are expected to exhibit better foaming under microwave heating. Three techniques generally produce EPS microspheres-syntactic foams; blending EPS with resin, expanding EPS during 
the curing process, and expanding EPS using thermal energy. However, all these techniques are limited due to the low extent of foaming and non-uniformity of the foamed structure [79,80]. In 2015, Yifeng Hong et al. [70] proposed microwaves as favorable for processing syntactic foams with high EPS loading. This is due to microwaves' advantages to penetrate the bulk of the material, overcoming heat transfer limitations, and more even foaming derived from volumetric heating. Moreover, a special feature of microwaves in this application is auto-limiting heating, which means that the material becomes less microwave absorbent once a foaming reaction occurs, and thereby, microwave energy will be preferentially absorbed by unreacted parts of the material [81]. Figure 3a shows the schematic diagram of EPS/epoxy syntactic foam fabrication using microwave heating. The author [70] studied the microwave foaming process's feasibility and optimized three parameters (microwave power, epoxy viscosity, and heating time). As shown in Figure 3a, the first step involved mixing a resin base and curing to achieve the desired mixture viscosity, which is the key parameter to produce the required surface structure of the product, as discussed in detail later. In the second step, EPS beads and hardener were mixed with resin. The purpose of hardener is to prevent dissolution and facilitate the homogenous distribution of beads. The third step is foaming of the mixture inside the mold using microwave heating and curing to stabilize the structure. The processing of foaming and curing is completed in few minutes, suggesting a fast and potentially energy saving process. During foaming, the foams can be easily molded into complex shapes such as " $\mathrm{E}$ " when microwave heating is employed (Figure $3 b$ ). The pressure generated during microwave foaming act as a driving force to achieve an efficient molding process successfully, ensuring sufficient adhesion or bonding between spheres. The resulting foam product exhibited smooth surface and homogenous distribution of pores, confirming an effective foaming process during microwave heating.

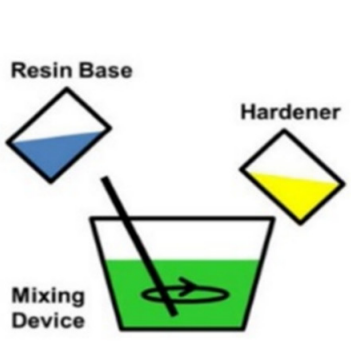

(A)

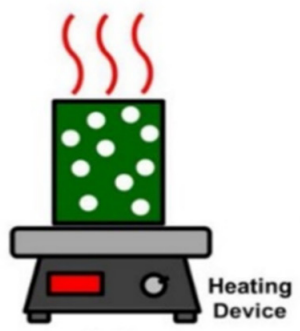

(F)

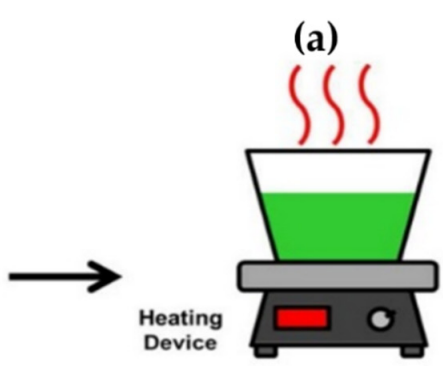

(B)

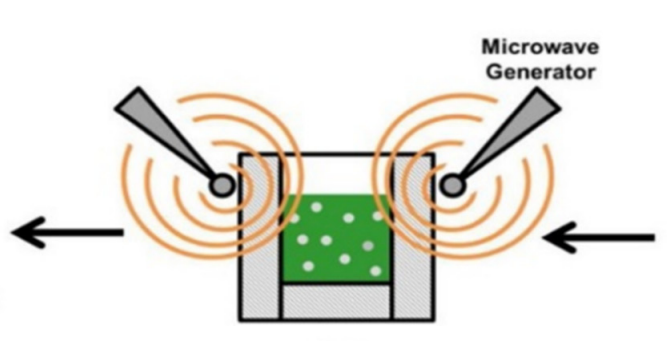

(E)

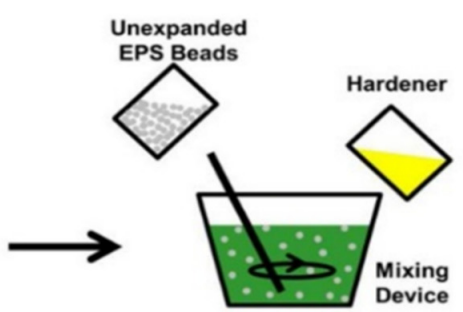

(C)

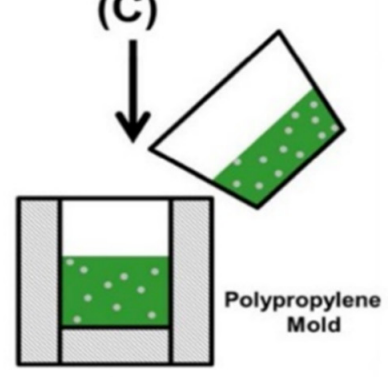

(D)

Figure 3. Cont. 
(b)

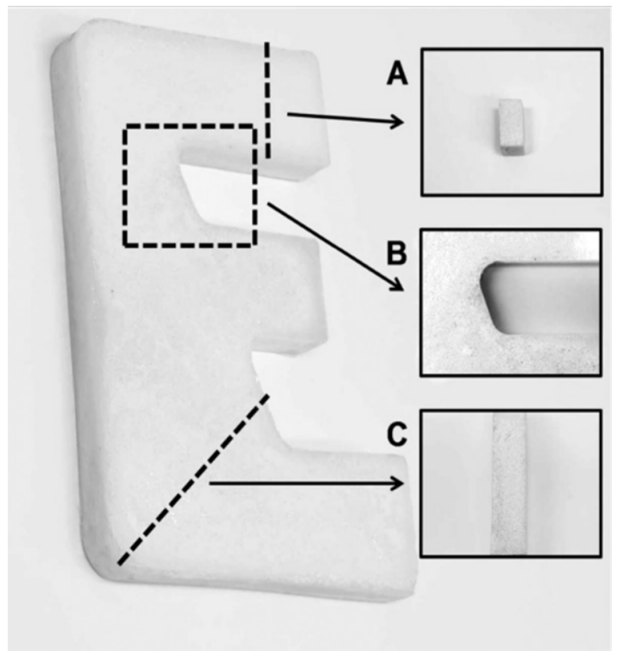

Figure 3. (a) Experimental setup for microwave expanding of epoxy-EPS syntactic foam: (A) mixing epoxy base and the first-part hardener, (B) pre-curing, (C) mixing unexpanded EPS microspheres, the second-part hardener, and the procured epoxy, (D) transferring foaming feed to a polypropylene mold, (E) microwave heating, and (F) post-curing]; (b) EPS-epoxy syntactic foamed letter "E" part molded via microwave expanding process: (A) cross-section of the upper arm, (B) magnified image of the upper curving section, and $(\mathrm{C})$ cross-section of lower curving section. Reprinted with permission from the authors of [70]. Copyright (C) (2015) Society of Plastic Engineers.

Similarly, Yifeng et al. [44] reported the fabrication of honeycomb-like EPS structures filled with fire retardant syntactic foam using microwave heating, as shown in Figure 4a. The process includes homogenous mixing of diluent, fire retardant, and unexpanded EPS followed by microwave heating, resulting in maximum expansion at 1000 watt $2.45 \mathrm{MHz}$ and $3 \mathrm{~min}$. Figure $4 \mathrm{~b}$ shows a thin barrier layer, which is due to the high loading of EPS during microwave foaming. This considerably enhanced the fire retardancy of the product without affecting the other foaming properties.

(a)

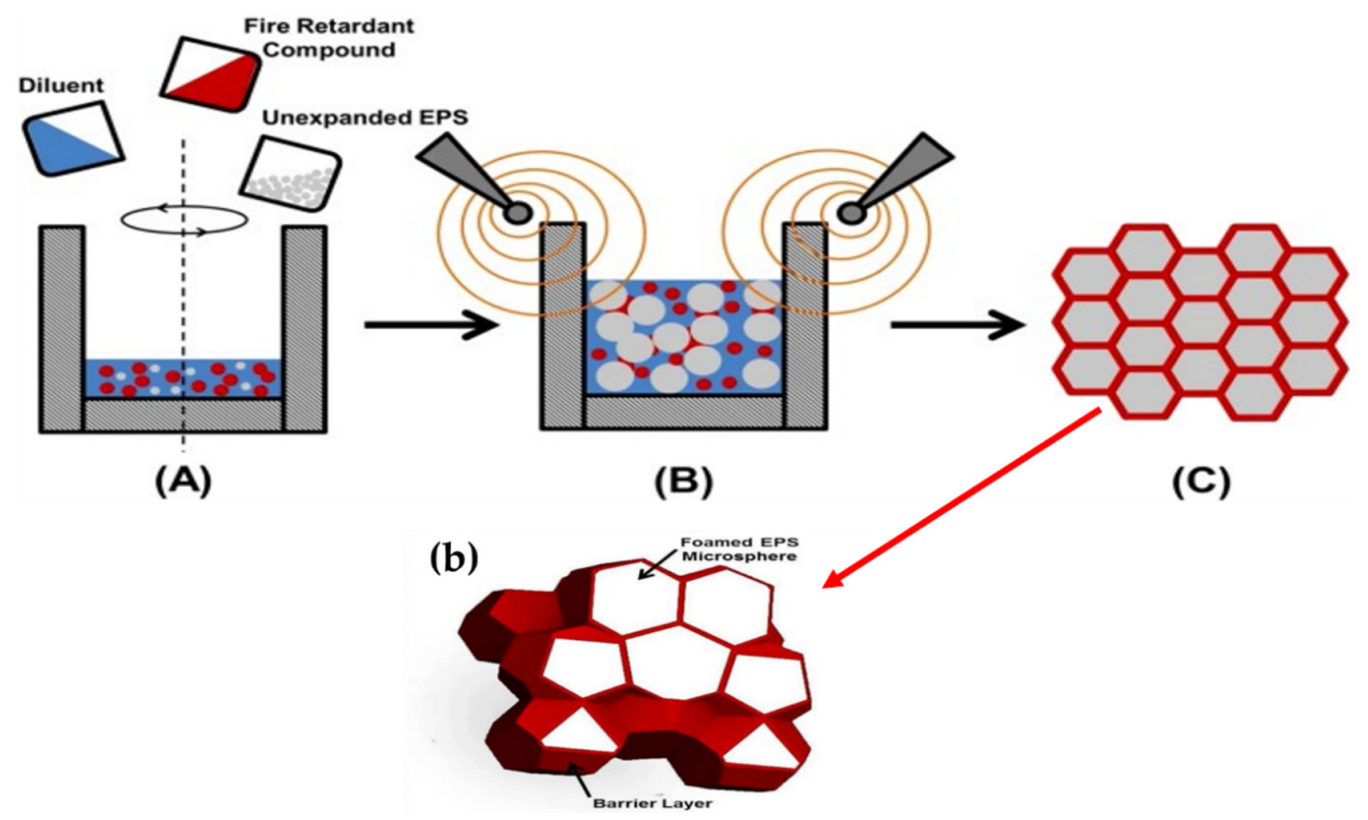

Figure 4. (a) Process setup and procedure to produce composite EPS foam from an expandable suspension; (b) composite EPS foam, a 3D pictorial model with cross-section. Reprinted with permission from the authors of [44]. Copyright (C) (2015) Society of Plastic Engineers. 


\subsection{Phenolic Foams}

Phenolic foams produced via microwave processing effectively overcome several environmental concerns linked to conventional foaming processes. During extruded foam production, phenolic foams typically require chlorofluorocarbon or hydro-chlorocarbon as a blowing agent. These substances pose a serious threat to the environment due to their high global warming potential. In addition, during foaming, these phenolic foams generate water as a byproduct, and this requires a simultaneous curing process, which is challenging to achieve uniformly using traditional heating. In 2008, Kim et al. [15] proposed and verified the fabrication of high-density phenolic foam (approx. $100 \mathrm{~kg} / \mathrm{m}^{3}$ ) using microwave heating. The presence of polar molecules in the phenolic resin can effectively absorb microwave energy, which led to a uniform and quick increase in temperature of the resin and resulted in the uniform cellular foamed product. The favorable process step is that, as the temperature goes above $100{ }^{\circ} \mathrm{C}$, the byproduct water and alcohol solvent start to escape from the foam matrix. This allows air to embed in the foam pores and thus significantly reduces the thermal conductivity of foam. Figure 5 shows the schematic diagram of the foaming process of phenolic foams. The process involves three main steps: (i) air bubbles embedding with resoling and hardener using an impeller, (ii) injection in the mold, and (iii) microwave expansion [15]. The idea of an embedded air bubble is due to the high viscosity of resoling, which prevents maximum expansion during foaming. As shown in Figure 5, the resole is expanded about $5-10$ times in the microwave foaming process to achieve low-density foam. This expansion is linked to the resole's temperature, which needs to reach $150-250{ }^{\circ} \mathrm{C}$ to produce a cellular product. Moreover, the presence of large voids is associated with a substantial increase in water volume to about 1000 times when it changes from liquid to gaseous phase during microwave heating at high temperatures. The author also attributed this phenomenon to the presence of unreacted phenols in the foam matrix.

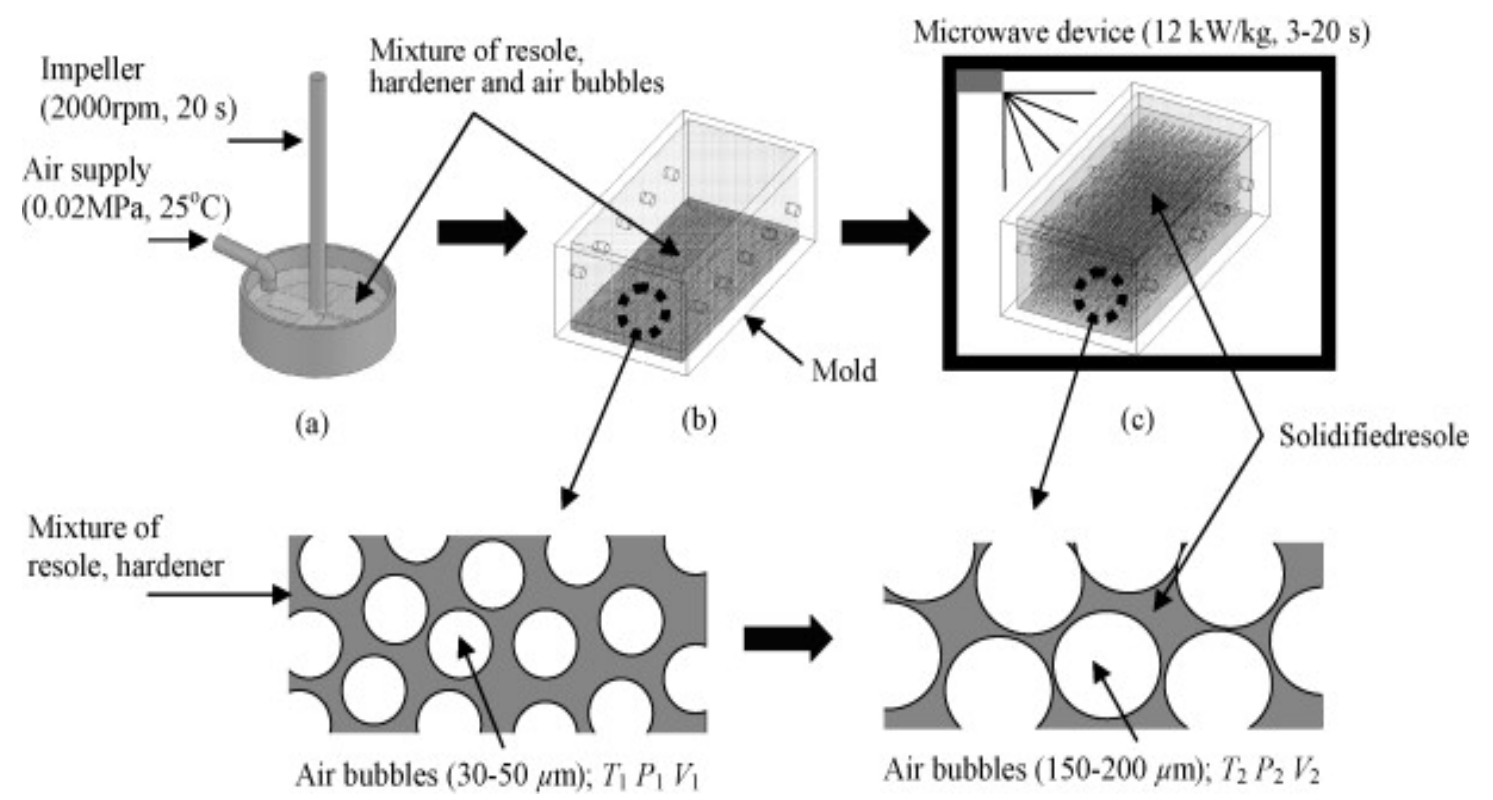

Figure 5. (a). Microwave foaming method: (a) mixing resole and hardener with air bubbles embedded, (b) injection to mold, and (c) microwave foaming. Reprinted with permission from the authors of [15]. Copyright (c) (2008) Elsevier.

A similar methodology was adopted by J. Choe et al. [47] to fabricate low-density phenolic foam using microwaves in the presence of chopped glass as a reinforcing material. A closed mold foaming was employed, and the average uniform foam density reported was $35 \mathrm{~kg} / \mathrm{m}^{3}$ and thermal conductivity of $0.039 \mathrm{Wm}-\mathrm{K}$, which were within a suitable range for insulating applications. The presence of chopped glass significantly enhanced the mechanical properties of foam without altering the insulating 
performance. Song et al. [68] studied the incorporation of carbon nanoparticles on phenolic foam using microwave heating from which they investigated the effect of carbon particles on the formation of the pores during foaming by changing resin viscosity and cross-linking.

\subsection{Modified Microwave Foaming Processes}

These techniques have been recently applied to produce different types of highly porous and adsorbent foams, such as $\mathrm{B}-\mathrm{C}-\mathrm{N}$ and $\mathrm{NiCr}$ foams. In this regard, Rajib Paul et al. [74] utilized a combined microwave-chemical processing technique for the surface treatment of carbon foams to produce boron-carbon-nitrogen (B-C-N) foam. This method involves the successful conversion of carbon foams to boron carbon nitride $(\mathrm{B}-\mathrm{C}-\mathrm{N})$ by microwave heating carbon foam in the presence of boric acid and urea solution, as depicted in Figure 6. Microwave influence on effective initiation of surface chemical reaction and annealing at $900{ }^{\circ} \mathrm{C}$ temperature resulted in the formation of foams containing high porosity and right stoichiometry between $\mathrm{BC}_{2} \mathrm{~N}$ and $\mathrm{BC}_{4} \mathrm{~N}$. The $\mathrm{B}-\mathrm{C}-\mathrm{N}$ is a hexagonal porous solid exhibiting a large surface area and high thermal conductivity, which is a suitable substrate for thermal energy storage and adsorption of hydrocarbons.

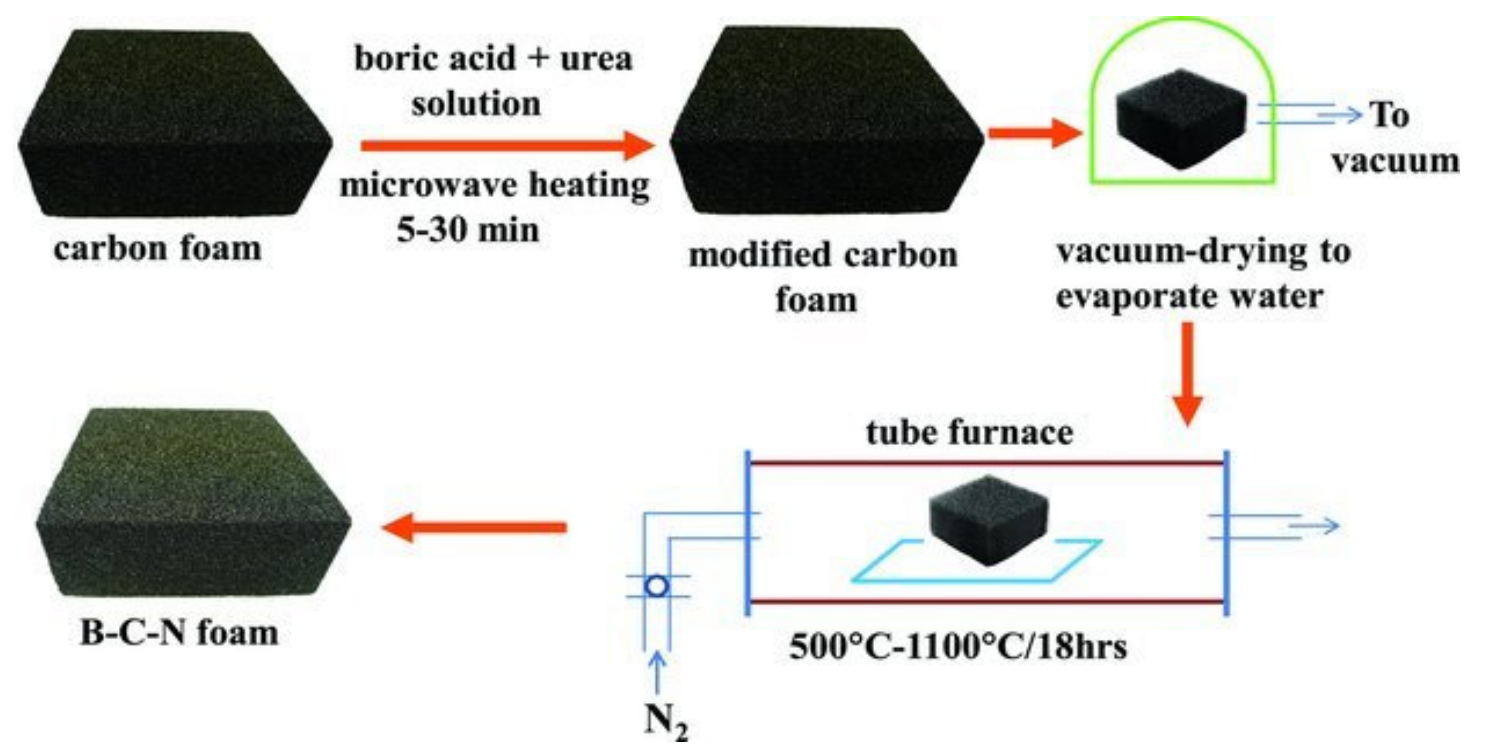

Figure 6. Schematic synthesis procedure of B-C-N foam from carbon foam. Reprinted with permission from the authors of [74]. Copyright (C) (2012) John Wiley \& Sons.

Microwave hybrid heating was adopted by Kangjian $\mathrm{Wu}$ et al. [45] to process $\mathrm{NiCr}$ foam by pyrolysis of polyurethane. These types of metallic foams are commonly produced by pyrolysis of polyurethane foams using conventional heating [82,83]. However, compared with conventional heating, using microwave-hybrid technology significantly reduces the processing time and residual carbon content in pyrolyzed foams - however, the formation of burst holes is due to the rapid degradation of polyurethane during microwave irradiation. The purpose of microwave hybrid heating is to overcome the homogeneity challenges associated with microwave systems. Usually, indirect microwave heating of metallic foams consists of sharp edges; the microwave energy concentrates at the foaming material [84], leading to the ignition of gas plasma (arcing) and overheating and melting of the material. Therefore, a combination of direct microwave heating with external coupled heating containing microwave susceptors such as $\mathrm{SiC}$ (high dielectric loss at low temperature) in the foaming process. The $\mathrm{SiC}$ susceptor weakens the microwave intensity at the sharp edge by efficiently absorbing microwaves, and this reduces the gas plasma ignition during microwave foaming. 


\section{Effect of Microwave Foaming Influential Factors on the Final Properties of Foamed Materials}

The final characteristics of microwave foamed materials such as density, thermal conductivity, expansion ratio, cellular structure (i.e., cell size, pore distribution, and porosity), and mechanical and thermal strength are greatly influenced by various microwaves operational factors. The key factors include water/moisture content (or blowing agent of foaming material), the viscosity of foaming suspension, microwave power (or power density), and time. In addition, precursor characteristics, including dielectric properties, blend ratios, and incorporation of additives, are also important. Therefore, this section comprehensively discusses the impact of these parameters on the microwave foaming process and their influence on the final microwave foamed materials' physical and thermal properties. A schematic illustration representing the microwave parameters effect on final foam properties is shown in Figure 7. This is expected to enhance readers' understanding of the microwave foaming mechanism and help comprehend the effect of altering or controlling these key influential factors on produced foamed characteristics.

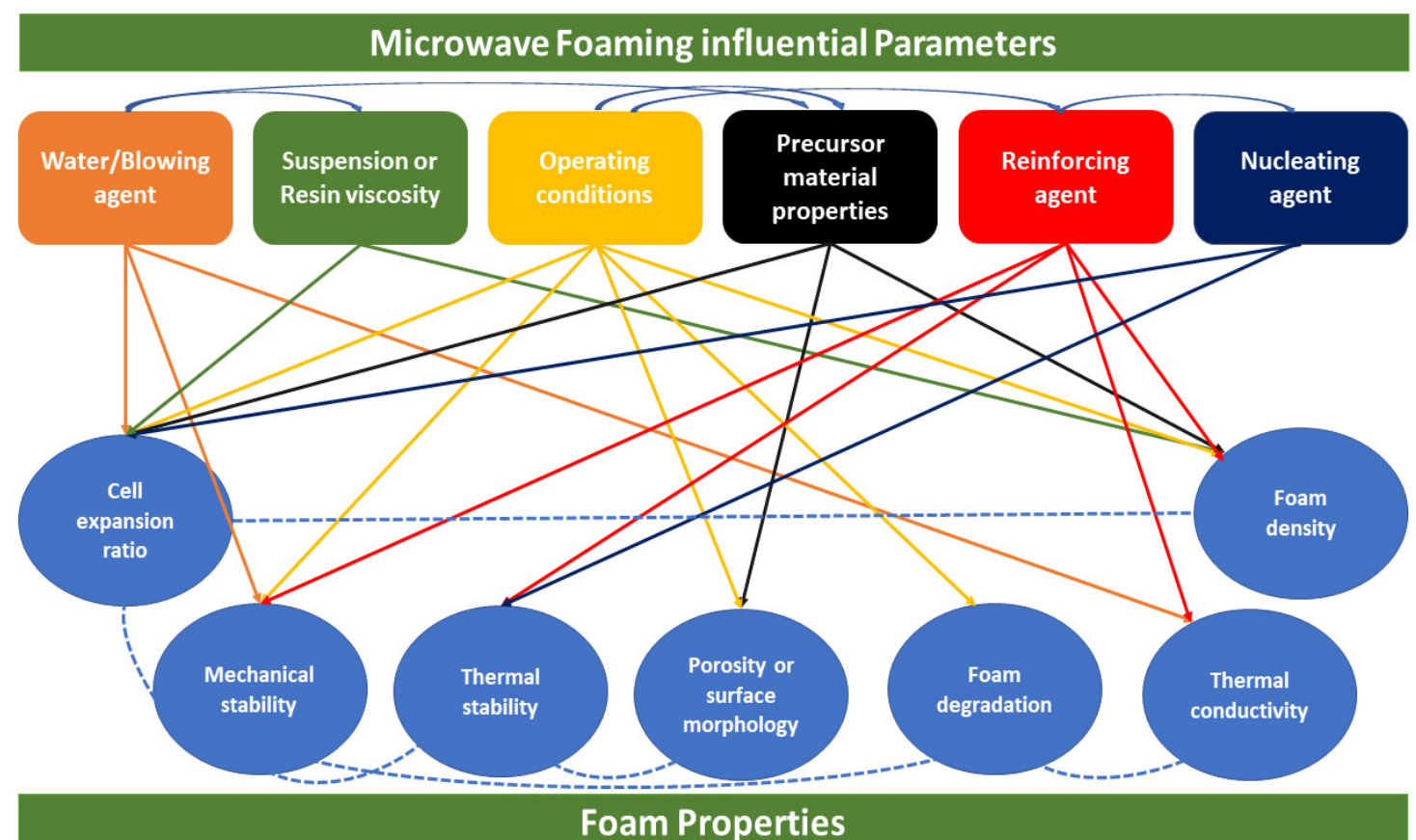

Figure 7. Microwave foaming influential parameters are affecting foam product properties.

\subsection{Effect of Water or Blowing Agent Content}

In microwave foaming processes, water content is an essential process parameter and is commonly employed as a blowing agent or plasticizer for the production of different foaming materials. During the microwave foaming process, water molecules are the main source of dipole movement and therefore provide a rapid increase in temperature due to its molecules' vibration. It is thought to produce superheated steam, which is the main driving force to induce the expansion of foaming materials. According to previous studies $[15,51,59,85]$, the percentage of water content before foaming or water loss during foaming directly affects the number of properties of the foamed product, including expansion ratio, density, and cellular structure, thermal conductivity, and mechanical properties. Many researchers have assessed the effect of water content or water loss (weight loss) before and during microwave foaming on microwave foams behaviors. According to the study credited to [86] Sjöqvist et al., the initial achieved foam expansion was low and was insufficient at low water content. However, a further slight increase in water content significantly enhanced the foam's expansion, producing porous and small density products. It was demonstrated that the water content $(\mathrm{RH})>60 \%$ ) resulted in a continuous decrease in the expansion, which the author attributed to the collapse of the formed foam cell after 
expansion. Similarly, as seen in Figure 8, the lowest density foams are obtained at $10 \% w / w$ moisture content for all the samples. An increase in the foam density by $>10 \%$ may be attributed to the reduction in expansion ratio due to loss in water during heating, a lower degree of selective heating of the water due to increased water content (i.e., lower power density in the water phase leading to lower steam pressure), and formation of a denser skin layer.

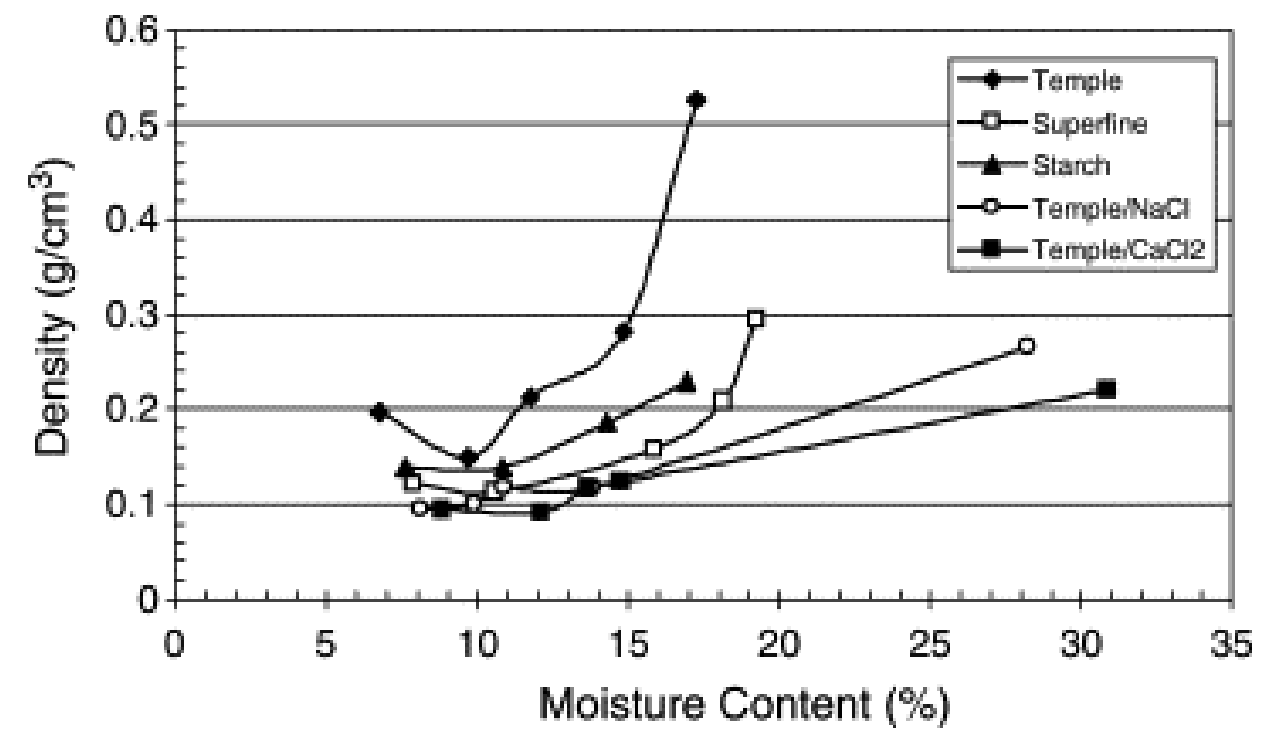

Figure 8. The densities of pellets microwave-foamed at different moisture contents. Reprinted with permission from the authors of [48]. Copyright (C) (2006) Elsevier.

This behavior is also confirmed by the micrograph analysis of low- and high-water content foamed products. Sjöqvist et al. [86] reported that the highest porosity achieved at 33\% $\mathrm{RH}$; however, high moisture content $(75 \% \mathrm{RH})$ resulted in a collapsed cell and thick skin. Similarly, 10\% $w / w$ moisture content showed the lowest density of $0.114 \mathrm{~g} / \mathrm{cm}^{3}$, which was increased with a high moisture content of foaming material (Figure 8). The author attributed this observation to the plasticizing effect, which reduces the tension generated inside the cell's walls during foaming. This possibly led to the reduction in expansion and also eventual collapsing of some cells, as confirmed by a previous study [86]. As proved by Jia Zhou et al. [48], the larger the water vapor pressure, the more the expansion and bubble growth burst and achieve lower density and improvement in fraction of open cells, which can be controlled by process parameters and additives. An additional blowing agent could be utilized further to enhance water vapor pressure [48]. Figure 9 illustrates the SEM micrograph of temple pellets with Hydrocerol ${ }^{\circledR}$ BIH and talc as additive. The micrographs result indicates no difference with or without BIH blowing agent because of the insufficient decomposition of the blowing agent during microwave foaming (Figure 9b). However, the incorporation of talc powder has substantially reduced the size of the foam cells. The cell section diameters are in the range of $0.2-0.8 \mathrm{~mm}$ and $50 \mu \mathrm{m}$ to $0.5 \mathrm{~mm}$ for $0.8 \% w / w$ talc powder and $0.2 \% w / w$ talc powder foam, respectively.

The percentage of water loss during microwave foaming was also investigated in some previous studies, which indicated a significant influence on the final foam product's characteristics. Usually, during microwave foaming, increasing the material's temperature leads to the generation of steam inside the matrix. Most of the steam escapes from the foam cell structure rather than being retained inside the cells. This leads to expansion and loss of weight (or loss of water) of material, which develops changes in the produced foam's properties. For microwave foaming of starch-based materials, water, acting as the blowing agent, also acts as a plasticizer.

Additionally, the continuous escaping of water from the matrix leads to expansion and a simultaneous increase in the final foam product's stiffness to stabilize the cellular structure that forms during microwave processing. Due to water loss, there is an increase in the glass transition temperature, 
and when it reaches greater than foam temperature, maximum foam expansion is achieved, and the structure of the foam is then stabilized [87].
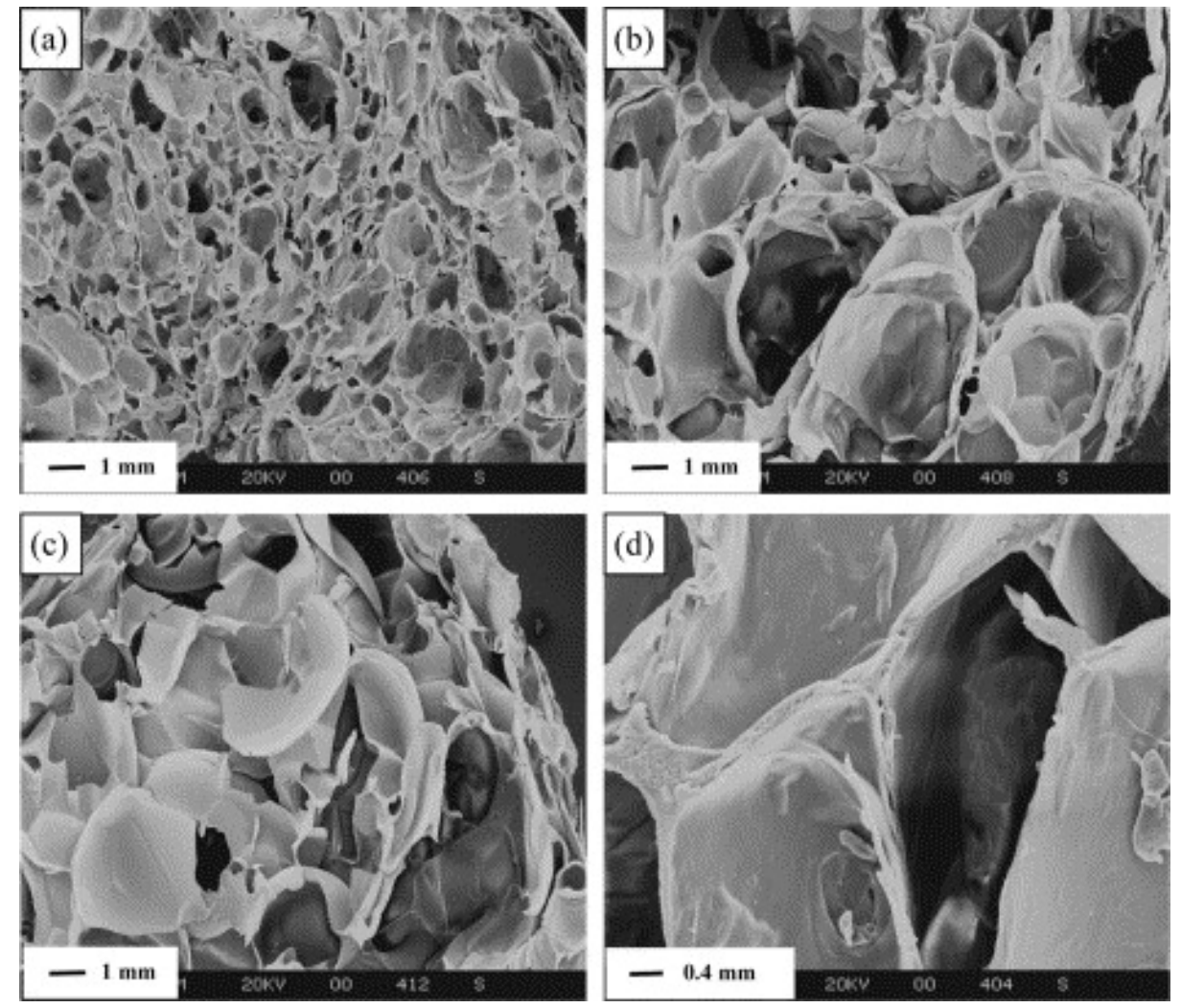

Figure 9. (a) Scanning electron micrographs of foamed temple pellets with various additives: (a) Temple; (b) Temple/BIH (1.5\% w/w); (c) Temple/talc $(0.8 \% w / w)$; (d) Temple/talc $(2.2 \% w / w)$. Reprinted with permission from [48]. Copyright (C) (2006) Elsevier.

Moreover, the water loss during microwave foaming results in a considerable increase in the foamed product's mechanical properties compared to the precursor. Using the cubic cell model proposed by Gibson and Asley [88], the estimated compressive modulus of starch foam by A.Lopez-Gil et al. [51] is found to be 50 times higher than the solid precursor. Flor Concenia and coworkers [56] reported that the presence of water in the foaming system of inorganic materials contributed well to homogenization and adsorbed within the micropores of materials, which helps in the formation of the macro-porous surface of foam because of its slow release during microwave foaming.

Bu Gi Kim and Dai Gil Lee [15] successfully fabricated low density and conductivity phenolic foams using air bubbles as blowing agents via microwave foaming techniques. The results (Figure 5) showed both open and closed cells at the center and closed near the ends. The authors associated large voids in foam structure due to water content evaporation from resoling during microwave foaming. Due to an increase in temperature, there is a substantial increase of about 1000 times in water volume when it changes from liquid to gaseous phase. The significant increase in volume during microwave foaming results in a drastic reduction of density and thermal conductivity of phenolic foam as compared to other produced phenolic products. Similar results were also reported in other studies $[47,89]$. Other workers also utilized other blowing agents such as pluronic, pentane, dichloromethane, sodium silicate, etc. during microwave foaming of different foamed materials (Table 2). Calles-Arriaga et al. [43] performed microwave foaming of polystyrene using ethanol, ethanol/water, and hydrogen peroxide as blowing agents. The authors revealed that, during EPS foaming, ethanol or ethanol/water promotes a sharp increase in temperature. However, the process produces moisture content as a byproduct, which requires extra microwave heating and the resultant foams exhibited easy detachment of EPS 
pearls. In contrast, using hydrogen peroxide instead facilitates low water content and strong attachment of the EPS pearls.

\subsection{Effect of Suspension/Resin Viscosity}

Viscosity is another factor with a significant impact on the final properties of materials foamed via microwaves. Therefore, in order to improve the properties during microwave foaming, it is highly recommended to select suitable viscosity for the foaming suspension/resin. However, very few studies have been conducted to investigate the behavior of changing mixture viscosity during microwave foaming on the foamed product's properties. Song et al. [68] reported that the resin viscosity for phenolic foams directly affects the cell density, indicating that the cell expansion can be controlled by resin viscosity. The authors further demonstrated that during microwave foaming, as the cross-linking begins, there is a strong enhancement in the resin viscosity, which hinders the pores' expansion. It was demonstrated that the incorporation of nanomaterials such as MWCNT caused a significant increase in resin viscosity, which showed large cells, presence of unblown particles, and high density foamed products [27]. However, graphene presence in reinforced phenolic foams showed much lower density and improved compressive strength, which was attributed to better and uniform graphene dispersion and lower resin viscosity [68].

Using ethanol to control the resin viscosity, Jacheon et al. [47] studied the effect of resin viscosity on the phenolic foam's density and cell structure and the percent of ethanol on the foam density. The results displayed in Figure 10a indicate that the foam density decreased from $37.7 \mathrm{~kg} / \mathrm{cm}^{3}$ to $18.3 \mathrm{~kg} / \mathrm{cm}^{3}$ when 20 percent ethanol was added. The author associated this variation with a significant reduction in resin viscosity at higher ethanol content, which considerably enhanced pores' expansion. According to the Rayleigh-Plesset equation [90], the velocity of bubbles formed during the microwave expansion process is inversely proportional to resin viscosity. Therefore, based on the hypothesis, for a low viscous resin, the expansion is more significant in a shorter time, producing larger cell size and lower foam density. Moreover, due to the broader expansion of cells, the low viscous resin foam's surface exhibited rough morphology compared to the smoother surface of high viscous resins as illustrated in Figure 10b,c, respectively.

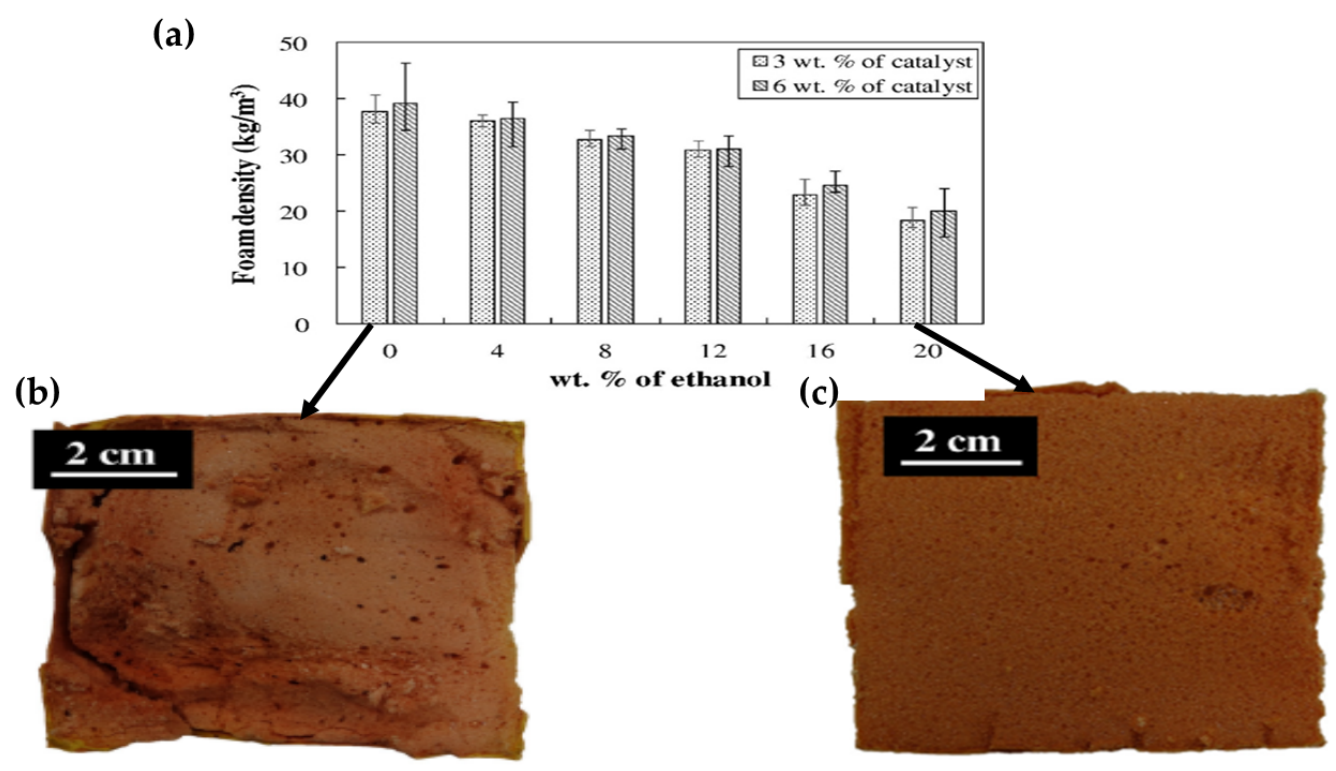

Figure 10. (a) Free rise phenolic foam density concerning the wt. $\%$ of ethanol; $(\mathbf{b}, \mathbf{c})$ photographs of the phenolic foams' cross-sectional views with three wt.\% of PTSA catalyst concerning the wt.\% of ethanol, $0 \mathrm{wt} \%$, and $20 \mathrm{wt} \%$. Reprinted with permission from the authors of [47]. Copyright (C) (2016) Elsevier. 


\subsection{Effect of Microwave Operating Variables}

Microwave operating parameters such as microwave power, exposure/heating time, and modified microwave foaming techniques-such as chemical assisted microwave or hybrid microwave heating-also have considerable influence on foamed products' density and cellular structure, which directly reflect the mechanical and thermal characteristics of foams. In 2012, Alexander et al. [69] studied the change in microwave heating time on the density, surface morphology, and strength of PU foam products. The authors reported that the increase in microwave exposure time at fixed power significantly altered their produced foams' strength and elasticity. Similarly, in 2013, S. Kraus et al. [66] investigated the effect of microwave power and system pressure on the expansion during the foaming process, with another study corroborating their findings [87]. It is indicated that the volume expansion increased with an increase in microwave power attributed to the linear increase in temperature inside the foaming material with an increase in microwave power, as supported by other previous studies [91,92]. Due to the high microwave power, the author concluded that the temperature inside the material was higher, which led to high vapor pressure and, hence, the enhanced volume expansion. Xi Peng et al. [64], evaluated the change in a dielectric loss concerning microwave power. It was observed that at a higher microwave power range of $150 \mathrm{~W} / \mathrm{g}-200 \mathrm{~W} / \mathrm{g}$, dielectric loss factor significantly jumped to over 0.3 even at a lower system temperature of $25{ }^{\circ} \mathrm{C}$ and remained at a steady-state up to temperature $160^{\circ} \mathrm{C}$. However, at a short microwave power range of $75 \mathrm{~W} / \mathrm{g}$ to $150 \mathrm{~W} / \mathrm{g}$, the dielectric loss remained significantly low between 0.05 to 0.1 and increased when the process temperature was greater than $80^{\circ} \mathrm{C}$. In another similar study [65], microwave power's effect on the pore distribution was evaluated. The pore distribution results showed that there is a significant increase in the nucleation rate of vapor bubbles at high microwave power, which led to a significant increase in the number of pores within small areas. By employing FTIR characterization, Demitri et al. [71] investigated the influence of microwave power and time using a highly interconnected and homogenous structure CS-PEGDA scaffold. It was revealed that the higher microwave heating time, i.e., $240 \mathrm{~s}$, possibly started the scaffold's thermal degradation as confirmed by the yellowing color of the product. Moreover, the microwave curing power was found to be independent of the reaction yield. In another study, the surface roughness of the final foam product was increased with increasing time of microwave chemical assisted foaming of carbon foams [74]. It is suggested that the increase in surface roughness can be attributed to the breakage of carbon bonds and creation of defects at more exposure time.

\subsection{Effect of Foam Precursor Materials Properties}

Foam precursor materials such as composition, molecular weight, dielectric properties, melt viscosity, and blend ratios in composite foams reflected considerable influence on the final physical properties such as density, cell wall thickness, and cell pore size, and mechanical and thermal stability of the foam. For instance, Jiang Zhou et al. [48] investigated three precursors (temple, superfine, and wheat starch) for producing starch-based foams via microwave. Based on morphology results, the temple starch-based foam material exhibited adequate cell structure associated with the presence of bran (outer layer of grains) in temple starch, which acts as a natural nucleating agent during the microwave foaming process. Other studies also reported similar behavior when foamed material using different techniques [93]. Apart from the composition of precursor materials, another essential characteristic is the foaming material's dielectric properties. Understanding change in dielectric constant $\left(\varepsilon^{\prime}\right)$ and loss $\left(\varepsilon^{\prime \prime}\right)$ is critical to understanding the fundamental mechanistic interactions between microwave energy and materials. Generally, during microwave heating, the increase in temperature inside the materials is due to the dielectric polarization of material indicated by its dielectric loss factor $[93,94]$. The dielectric loss factor $\left(\varepsilon^{\prime \prime}\right)$ is defined as the efficiency of material to convert the electric energy to thermal energy. A high dielectric constant means high microwave energy absorption capability [62]. The dielectric loss $\left(\varepsilon^{\prime \prime}\right)$ in the range of 0.05 to 5 of a material indicates that the material can be foamed using microwave energy [46]. In several studies, the authors of the respective studies have reported the dielectric properties of foaming material to understand the microwave 
foaming mechanism. Peng et al. [64] investigated the dielectric loss of dry starch and extruded starch material (at different moisture content) at an increased temperature rate of $15^{\circ} \mathrm{C} / \mathrm{min}$ using controlled microwave foaming. The author reported no change in the dielectric loss factor of dry starch. The sharp jump of $\varepsilon^{\prime \prime}$ at temperature defined as $T_{\mathcal{\varepsilon}}$ of extruded starches is observed at the temperature corresponding to close to glass transition temperature $\left(\mathrm{T}_{\mathrm{g}}\right)$. Therefore, the temperature $100-110{ }^{\circ} \mathrm{C}$ above $T_{\varepsilon}$ is the actual foaming temperature of extruded starches. As the temperature reached above $\mathrm{T}_{\mathrm{g}}$, the mobilization of amorphous starch segments started and promoted easy dipoles to orient along the electric field's direction. This resulted in more conversion of electric energy to thermal energy due to intermolecular friction during the oscillation of dipoles, which lead to the quick rise in $\varepsilon^{\prime \prime}$. In another study, the dielectric properties of a starch material were investigated at different moisture contents and were correlated with the porosity of foamed product [66]. The study reported that the dielectric properties showed increasing trend with an increase in moisture content which resulted in high expansion in foam cell volume and a more porous product. Moreover, as seen in Figure 11a-d, Jiang Zhou et al. 48], observed different cell structure and size of foam produced from Temple flour, superfine flour, and purified wheat starch. Higher proportions of large cell sizes $(0.5-4 \mathrm{~mm})$ are found in superfine and purified wheat flour. However, temple flour exhibited finer and smaller cell size $(0.2-2 \mathrm{~mm})$ foam structure associated with the presence of bran, which acts as a nucleating agent. It is interesting to note that temple starch's compressive stress is higher than that of superfine and wheat flour foams. Commercial foams such as EPS (as a cushion block) and a wheat flour loose-fill used for protective packaging exhibited lower compressive strength than that of temple starch foam produced via microwave heating (Figure 11e).
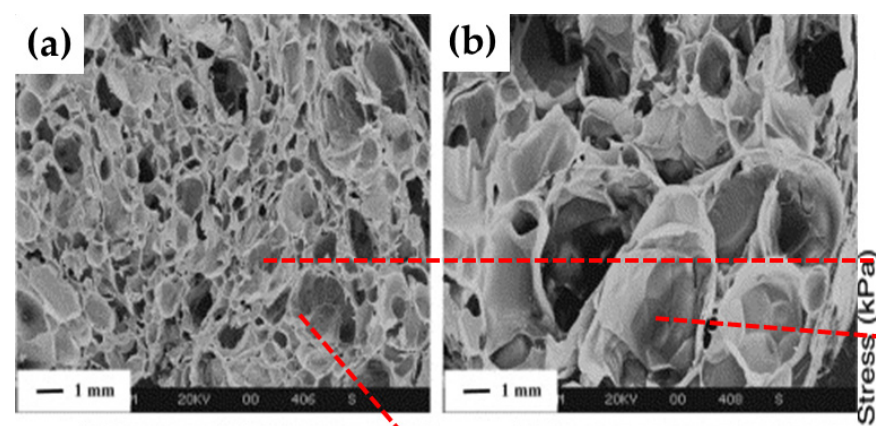

(e)
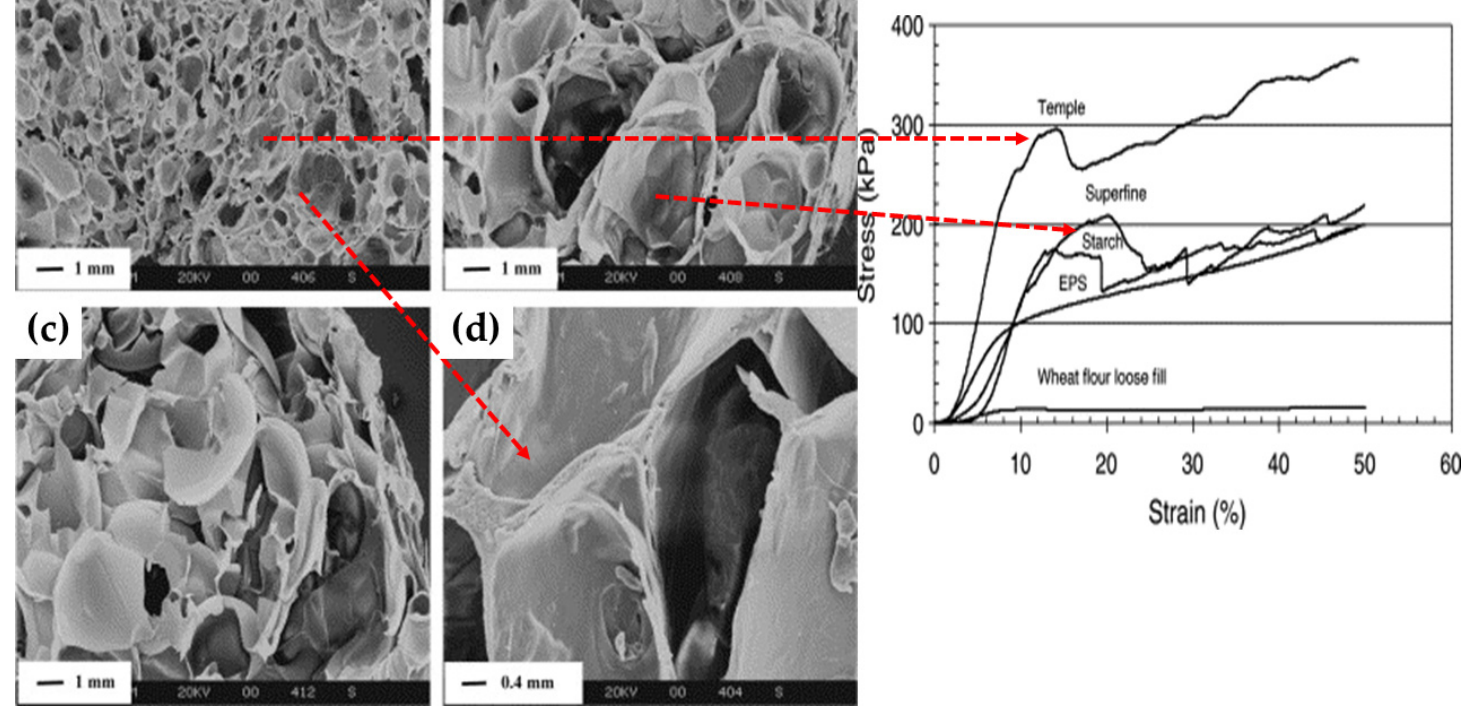

Figure 11. Scanning electron micrographs of cross-sections of foamed pellets with different raw materials: (a) temple flour, (b) superfine flour, (c) purified wheat starch, and (d) cell wall in temple foam shown in (a) at higher magnification. (e) Comparison of typical compressive stress-strain curves $\left(22{ }^{\circ} \mathrm{C}, 50 \% \mathrm{RH}\right)$ for the microwave-foamed pellets made from different raw materials with commercial protective packaging materials. Reprinted with permission from the authors of [48]. Copyright (C (2016) Elsevier.

\subsection{Effect of Reinforcing Agents}

The foamed product's mechanical and thermal stability is another crucial property in its application in various fields such as packaging, construction, automotive, etc. [95-97]. Therefore, it is highly essential to fabricate foams with reduced density and better stability in strong and rigid structures. To achieve this, various reinforcing agents, which include natural fibers, carbon materials, and other 
nanoparticles, have been incorporated into the foaming material to enhance product stability and understand their effects on the foaming process and properties of foam products. The selection of a proper reinforcing agent is also crucial to achieving better interaction and homogenous dispersion within the foaming matrix to produce effective reinforcement without altering the other foamed products' other properties. Lopez et al. [51] reinforced starch foam using three different types of natural fibers (barley, grape, and cardoon) (Figure 12). Effective embedding of all three fibers with the starch during microwave foaming resulted in foam with improved strength and rigidity comparable to that of pure starch foam. As seen in Figure 12a-d, the expansion of foam and cell size was lowered due to fillers' addition. Several cracks and holes within the cell walls for all the produced foams implying the strong interconnected cellular structure of the foam. This is attributed to the heterogeneous nucleation rate/better interaction with starch matric that induces smaller cell size [76] and thus produced a more robust foam structure than others.

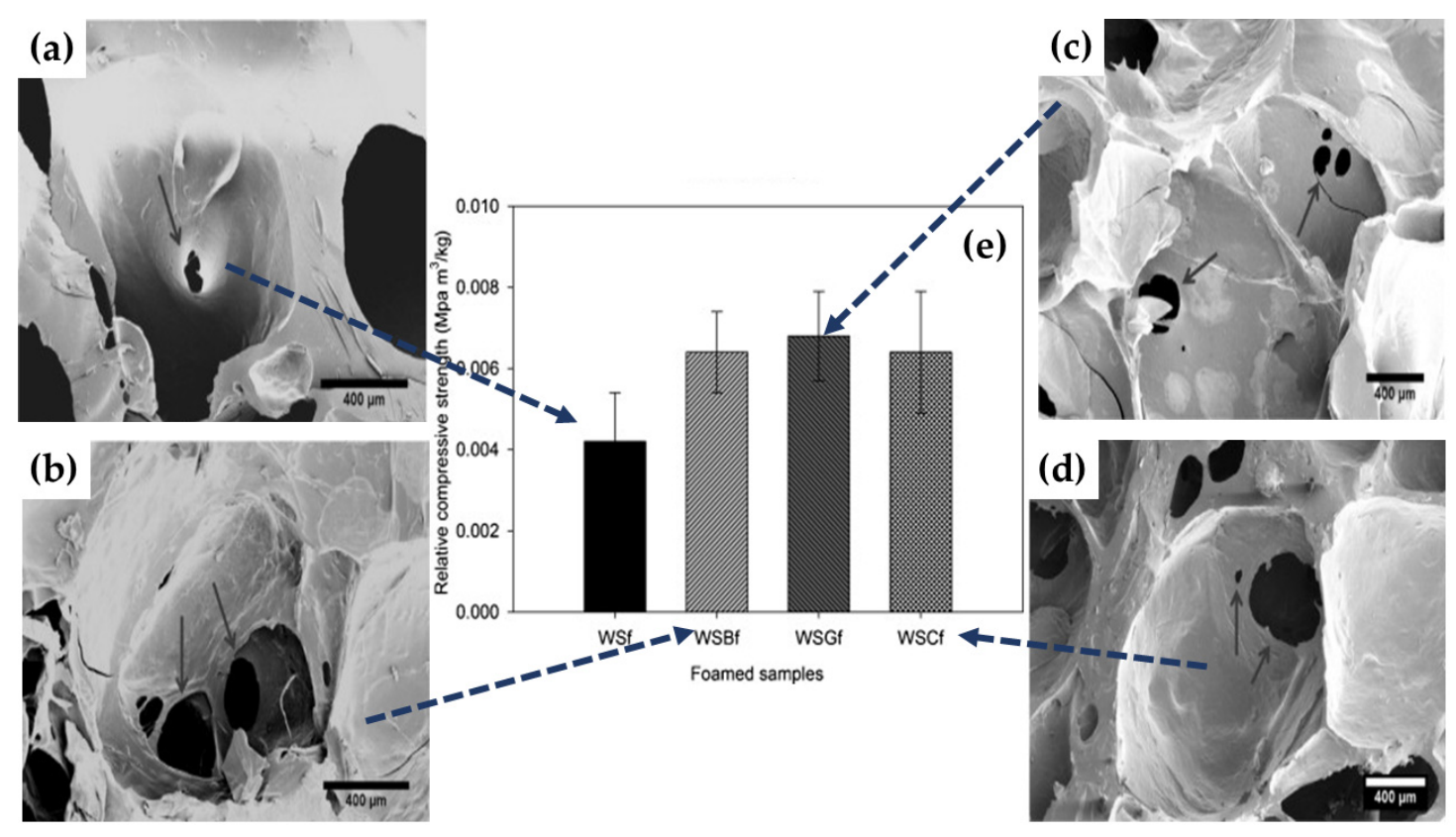

Figure 12. SEM micrographs of cells interconnected. (a) Wheat starch (WSf) $(60 \times)$, wheat starch starch-grape-barley (WSBf) $(60 \times)$ (b), (c) wheat starch-grape (WSGf) (40×), and (d) wheat starch-cardoon (WSCf) (40X). (e) Relative compressive strength of the foams produced. Reprinted with permission from the authors of [51]. Copyright (C) (2015) Elsevier.

Carbon nanomaterials exhibit high mechanical and thermal strength and attracted greater attention to use as a reinforcing agent in different foaming materials $[98,99]$. This carbon material class also exhibited a high dielectric loss factor and can be a potential candidate as a nucleating agent during microwave foaming [100]. Song et al. [52] improved the toughness, strength, and thermal conductivity of phenolic foam using AC. Studies have reported that AC's presence within the phenolic resin didn't only induce a reinforcing effect but also acted as a barrier for escaping water molecules during the microwave foaming process. As a consequence, it significantly facilitated an increase in the cell size and reduction in the density of the foam and more satisfactory cell walls. However, higher content of AC is susceptible to agglomeration in phenolic foams. It tends to lead to the degradation of foam products due to a large amount of heat generation upon exposure to microwave radiation [100,101]. In a similar study, carbon black was used along with a blowing agent to produce PU foam. The study found that carbon black presence promoted the formation of a uniform, fine cell structure in larger quantities compared to neat polyurethane foam. This can be ascribed to improved microwave absorption due to the incorporation of carbon black, leading to more effective heating and benefiting the finer cellular structure [69]. 
However, when MWCNT and graphene were utilized for improving the stability of phenolic foam produced by microwave energy, there was a decrease in the dissipation factor of phenolic foam containing MWCNT and graphene compared to neat phenolic foam. An increase in phenolic resin's viscosity by incorporating nanoparticles can restrict the dipole movement and thus effected the cell formation and reduction in expansion during microwave foaming. The catalytic reaction of MWCNT with phenolic resin induced by microwave heating also causes cross-linking and thereby decreases the rate of gas expansion during microwave foaming and resulted in interconnected cellular structure (Figure 13b). The addition of MWCNT and graphene in appropriate amounts significantly improved the mechanical and thermal conductivity (Figure 13e,f). Moreover, Figure 13c,d showed aggregates within the polymer matrix. Air bubbles trapped between the nanoparticles expand dramatically and create a large bubble due to intense microwave absorption and lead to large cavities in the foam structure [68]. To overcome the viscosity problem during microwave foaming of phenolic foams containing reinforcing agents, Choe et al. [47] utilized ethanol to foam chopped glass fiber $(3 \mathrm{~mm})$-phenolic foam. There was an approximate, 17 percent increase in tensile strength with $1 \mathrm{wt} \%$ chopped glass fiber without disturbing the physical and thermal properties of foamed product.
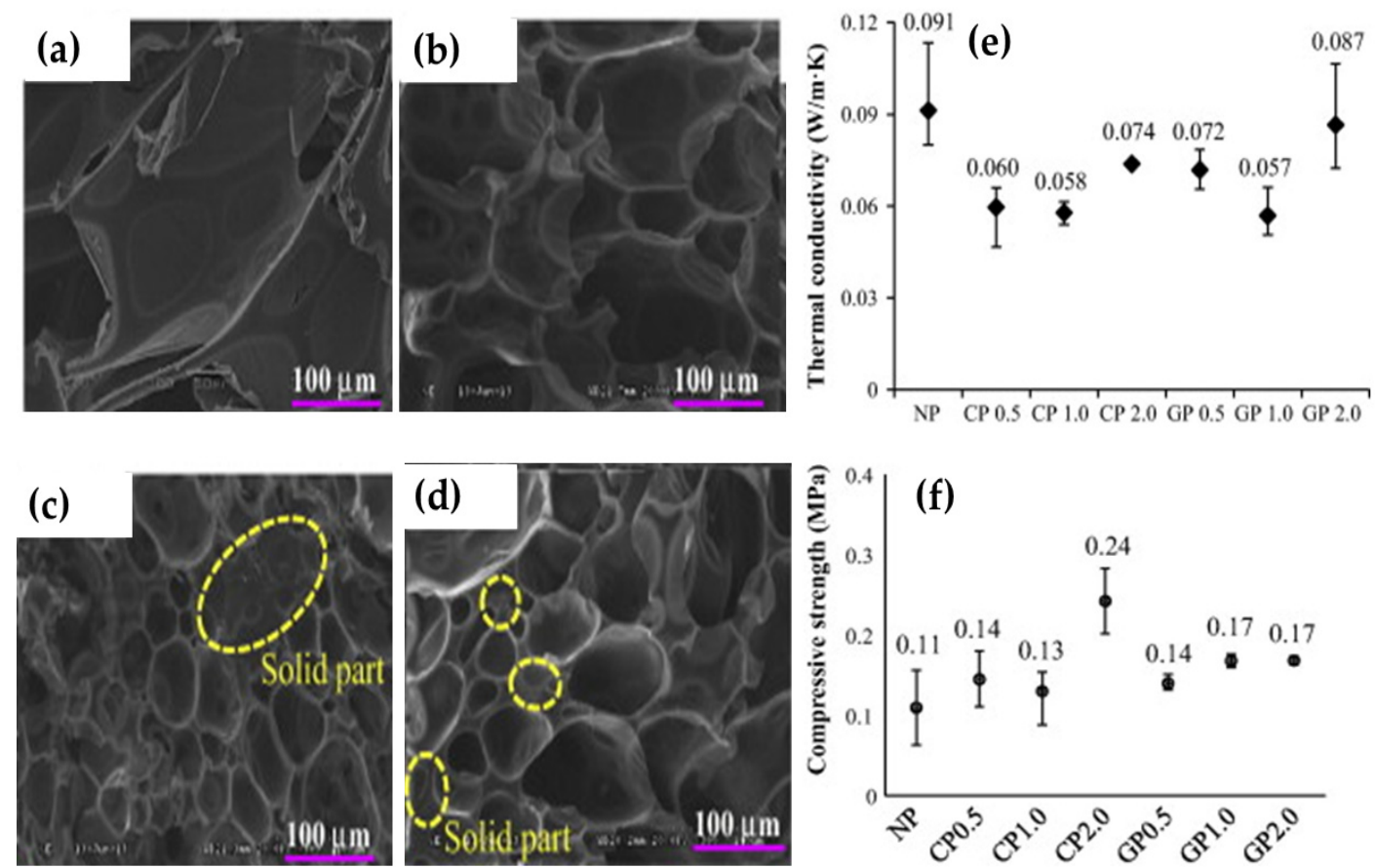

Figure 13. Scanning electron microscope images of (a) neat phenolic foam (NP), (b) phenolic foam with $0.5 \%$ multi-wall carbon nanotube (CP 0.5), (c) phenolic foam with $2 \%$ multi-wall carbon nanotube (CP 2.0), (d) phenolic foam with 2\% graphene (GP2.0), (e) thermal conductivity, and (f) compressive strength of produced foams with respect to the particle type and weight fraction. Reprinted with permission from the authors of [68]. Copyright (C) (2014) Elsevier.

\subsection{Effect of Additives/Nucleating Agents}

Additives and nucleating agents improve microwave foaming behavior by absorbing microwave energy to provide effective heating within the foaming matrix. They also help to produce bubble growth by enhancing bubble pressure inside the matrix. Various types of additives such as salts, talc, iron oxide, glycerol, and $\mathrm{PVOH}$ have been utilized and also investigated to evaluate their effects on microwave foaming behavior and final properties of foam products. It is necessary to determine the appropriate mass of additives and its uniform distribution within the foaming matrixand viscosity changes that lead to significant negative alteration in foaming behavior and finished foam properties. Improved microwave absorbing properties using additives allow increasing materials 
temperature, which causes decomposition of a blowing agent and leads to cellular foams' formation. Therefore, non-homogenous distribution of additives/microwave absorbers or their agglomeration causes the degradation of foam, attributed to localized heating and eventual cell collapse [58]. Moreover, the addition of additive may alter the viscosity and the glass transition temperature of foaming materials. These changes in precursor properties lead to a decrease in the movement of molecules during microwave foaming. As reported by Peng el at [43], they require high energy for expansion while using glycerol and $\mathrm{PVOH}$ for the production of starch foams.

\section{Discussion: Towards the Development of Industrial-Scale Microwave Foaming Processes}

A comprehensive explanation of the theory of microwave heating and its application to materials synthesis are well-defined and are available elsewhere in the literature [58]. The key parameters for foaming microwave processing and applications are dielectric properties (i.e., nature and extent to which materials interact with the microwave electric field at the molecular level); power density, the dissipation of the electric field within a material; penetration depth of the electric field into the material; and the overall electric field distribution. There are clear benefits and opportunities for microwave heating in foaming. There is currently a lack of understanding of these parameters, with little or no studies considering them in designing and developing experiments and microwave heating systems-for example, in the sample size of materials, the power and time variables, and the overall dielectric loading with microwave heating cavities.

As this review demonstrates, the application of microwave heating for the lab-scale production of foamed materials requires a multidisciplinary understanding of several fields, including polymer chemistry, materials science, chemical engineering, and manufacturing. Scaling up of microwave processes from the lab to industrial-scale needs understands these areas and dielectric characterization to inform microwave systems design. Due to the high cost of microwave technology compared to other processes, it is also critical to understand the value proposition for microwaves, i.e., what microwaves can do that no other technology can. Table 3 gives some example value propositions for microwave technologies that could apply to microwave foaming.

Table 3. The possible value proposition of microwave foaming applications.

\begin{tabular}{lll}
\hline & \multicolumn{1}{c}{ Opportunity } & \multicolumn{1}{c}{ Challenge } \\
\hline Environmental & $\begin{array}{l}\text { Microwaves can selectively heat water } \\
\text { (high dielectric loss) within the matrix, } \\
\text { allowing use as a sustainable } \\
\text { blowing agent. }\end{array}$ & Stable addition of water into a polymer matrix \\
\hline & $\begin{array}{l}\text { Produce controlled pore structures enabled } \\
\text { by instant control of heating }\end{array}$ & Electromagnetic design of homogeneous electric \\
Product quality & per unit of precursor & field distribution at large scale \\
& $\begin{array}{l}\text { Microwave technologies scalable/can fit in } \\
\text { a container enabling small scale } \\
\text { local/mobile processing }\end{array}$ & $\begin{array}{l}\text { Understanding sensitive of systems to feedstock } \\
\text { variation and incorporating into the } \\
\text { electromagnetic design of a system }\end{array}$ \\
\hline $\begin{array}{l}\text { Distributed manufacture based on } \\
\text { feedstocks/precursors, e.g., packaging }\end{array}$ & $\begin{array}{l}\text { Microwaves apply rapid selective and } \\
\text { volumetric heating. }\end{array}$ & $\begin{array}{l}\text { Understanding whether reduced OPEX can offset } \\
\text { increased CAPEX for microwave systems }\end{array}$ \\
\hline $\begin{array}{l}\text { Reduced processing time and energy } \\
\text { consumption }\end{array}$ & $\begin{array}{l}\text { Expansion of higher dielectric loss beads } \\
\text { within a microwave transparent matrix }\end{array}$ & $\begin{array}{l}\text { Controlled expansion and hardening/curing } \\
\text { of materials }\end{array}$ \\
\hline $\begin{array}{l}\text { New composites, e.g., polymer } \\
\text { syntactic foams }\end{array}$ & & \\
\hline
\end{tabular}

\section{Conclusions and Future Recommendations}

There have been significant advances in the application of microwave processing techniques to produce a variety of foamed materials over the last two decades. This has reduced process time, energy consumption, and solvent-free processing at the laboratory and pilot scale, avoiding environmental concerns while sometimes allowing significant improvements in product quality. The critical challenges in microwave foaming of materials indicate the future focus for research activities in this field to enable scale-up and adoption within manufacturing environments: 
- Utilization of new or sustainable higher dielectric loss blowing agents, e.g., water or their new combinations, to achieve better dispersion and foaming of different matrix materials that are incredibly transparent to microwaves. This is expected to provide effective heating and bubble growth and resulted in low-density cellular foams while overcoming the reliance on less sustainable blowing agents such as HCFCs and pentane.

- Dielectric characterization of foaming materials, additives, and blowing agents is highly desirable to understand better the microwave interaction with these materials, the importance of foaming temperature, and the overall foaming process. This will underpin not only the formulation of matrix-blowing agent-filler systems but also the design of bespoke microwave heating applicators and scale-up to industrial production.

- Rheological measurements such as viscosity, melt strength, and elongation strength are also vital issues required for providing an in-depth understanding of ways for controlling foaming, bubble stabilization, collapse, and expansion ratios for the production of foams with the desired requirements. Coupling this understanding with dielectric characterization also provides an opportunity to refine microwave heating protocols further.

- Use of nanofillers/modified fillers for both reinforcement and as nucleating agents for facilitating the foaming process in stabilizing bubbles growth. This is expected to result in higher expansion, low density, and thermally and stable mechanical foams.

- Modified microwave foaming techniques such as chemical-assisted microwave foaming in helping to induce cross-linking, branching, or degradation before foaming to achieve better foaming reduces the risk of cell collapse, improved expansion, and lower density cellular morphology of product, which has thus far proved challenging in some microwave foaming applications

- Development of new composite structures, e.g., syntactic polymer composites which cannot be readily produced using conventional foaming technologies

Author Contributions: M.Z. was involved with the concept and in the writing of the manuscript; R.F. gathered literature and assisted in review; O.A. reviewed and provided financial assistance; N.D.M. and N.I.B. reviewed; I.S.A. and M.S.M. assisted in gathering literature and finalizing tables and figures. All authors have read and agreed to the published version of the manuscript.

Funding: The authors acknowledge the funding provided by the Deanship of Scientific Research (DSR) at Imam Abdulrahman Bin Faisal University (IAU) in Saudi Arabia through research project No. 2018-044-Eng.

Conflicts of Interest: The authors declare no conflict of interest

$\begin{array}{ll}\text { Abbreviations } & \\ \text { EPS } & \begin{array}{l}\text { Expanded polystyrene } \\ \text { expanded polyethylene }\end{array} \\ \text { EPE } & \text { Expanded Polyurethane } \\ \text { EPU } & \text { Poly(lactic acid) } \\ \text { PLA } & \text { Moisture content } \\ \text { MC } & \text { Activated carbon } \\ \text { AC } & \text { Multi-wall carbon nanotubes } \\ \text { MWCNT } & \text { Expansion index } \\ \text { EI } & \text { p-toluenesulfonic acid } \\ \text { PTSA } & \text { Bottom ash } \\ \text { BA } & \text { Azodicarbonamide } \\ \text { ADC } & \text { Thermoplastic polyurethanes } \\ \text { TPUR } & \text { Carbon black } \\ \text { CB } & \text { Operating expense } \\ \text { OPEX } & \text { Capital expense } \\ \text { CAPEX } & \text { Polyvinyl alcohol } \\ \text { PVOH } & \text { NaCl } \\ \text { Sodium chloride } & \text { CaCl } 2 \\ \text { Calcium chloride } & \text { Hydrocerol } \\ \text { BIH } & \text { Moisture content } \\ \text { MC } & \text { Sodium silicate } \\ \text { SS } & \end{array}$




$\begin{array}{ll}\text { PEGDA } & \text { Polyethylene glycol diacrylate } \\ \text { CS } & \text { Chitosan } \\ \mathrm{Ti} & \text { Titanium } \\ \mathrm{Al} & \text { Aluminum } \\ \mathrm{BC} & \text { Boron carbide } \\ \text { PCL } & \text { Poly(caprolactone) } \\ \mathrm{DCM} & \text { Dichloromethane } \\ \mathrm{BPO} & \text { Benzoyl peroxide } \\ \text { PTFE } & \text { Polytetrafluoroethylene } \\ \mathrm{NiCr} & \text { Nickel-chromium } \\ \mathrm{SiC} & \text { Silicon carbide } \\ \mathrm{RH} & \text { Relative humidity } \\ \mathrm{EPDM} & \text { Ethylene-propylene-diene } \\ \text { PP } & \text { Polypropylene }\end{array}$

\section{References}

1. Muñoz-Pascual, S.; Saiz-Arroyo, C.; Vuluga, Z.; Corobea, M.C.; Rodriguez-Perez, M.A.J.P. Foams with Enhanced Ductility and Impact Behavior Based on Polypropylene. Composites 2020, 12, 943.

2. Kiss, G.; Rusu, G.; Peter, F.; Tănase, I.; Bandur, G.J.P. Recovery of Flexible Polyurethane Foam Waste for Efficient Reuse in Industrial Formulations. Polymers 2020, 12, 1533. [CrossRef] [PubMed]

3. Barroso-Solares, S.; Cimavilla-Roman, P.; Rodriguez-Perez, M.A.; Pinto, J.J.P. Non-Invasive Approaches for the Evaluation of the Functionalization of Melamine Foams with In-Situ Synthesized Silver Nanoparticles. Polymers 2020, 12, 996. [CrossRef]

4. Pinto, J.; Barroso-Solares, S.; Magrì, D.; Palazon, F.; Lauciello, S.; Athanassiou, A.; Fragouli, D.J.P. Melamine Foams Decorated with In-Situ Synthesized Gold and Palladium Nanoparticles. Polymers 2020, 12, 934. [CrossRef] [PubMed]

5. Pinto, J.; Athanassiou, A.; Fragouli, D. Surface modification of polymeric foams for oil spills remediation. J. Environ. Manag. 2018, 206, 872-889. [CrossRef] [PubMed]

6. Ng, Z.C.; Roslan, R.A.; Lau, W.J.; Gürsoy, M.; Karaman, M.; Jullok, N.; Ismail, A.F.J.P. A Green Approach to Modify Surface Properties of Polyurethane Foam for Enhanced Oil Absorption. Polymers 2020, 12, 1883. [CrossRef]

7. Notario, B.; Pinto, J.; Rodríguez-Pérez, M.A. Towards a new generation of polymeric foams: PMMA nanocellular foams with enhanced physical properties. Polymer 2015, 63, 116-126. [CrossRef]

8. Pinto, J.; Escudero, J.; Solórzano, E.; Rodriguez-Perez, M.A. A novel route to produce structural polymer foams with a controlled solid skin-porous core structure based on gas diffusion mechanisms. Materials 2020, 22, 822-832. [CrossRef]

9. Soykeabkaew, N.; Thanomsilp, C.; Suwantong, O. A review: Starch-based composite foams. Compos. Part A Appl. Sci. Manuf. 2015, 78, 246-263. [CrossRef]

10. Demitri, C.; Raucci, M.G.; Giuri, A.; De Benedictis, V.M.; Giugliano, D.; Calcagnile, P.; Sannino, A.; Ambrosio, L. Cellulose-based porous scaffold for bone tissue engineering applications: Assessment of hMSC proliferation and differentiation. J. Biomed. Mater. Res. Part A 2016, 104, 726-733. [CrossRef]

11. Nofar, M.; Park, C.B. Poly (lactic acid) foaming. Prog. Polym. Sci. 2014, 39, 1721-1741. [CrossRef]

12. Gardziella, A.; Pilato, L.A.; Knop, A. Phenolic Resins: Chemistry, Applications, Standardization, Safety and Ecology; Springer Science \& Business Media: New York, NY, USA, 2013.

13. Zhang, F.; Zhou, T.; Liu, Y.; Leng, J. Microwave synthesis and actuation of shape memory polycaprolactone foams with high speed. Sci. Rep. 2015, 5, 11152. [CrossRef] [PubMed]

14. Shen, L.; Wang, J.; Xu, G.; Li, H.; Dou, H.; Zhang, X. NiCo2S4 Nanosheets Grown on Nitrogen-Doped Carbon Foams as an Advanced Electrode for Supercapacitors. Adv. Energy Mater. 2015, 5, 1400977. [CrossRef]

15. Kim, B.G. Development of microwave foaming method for phenolic insulation foams. J. Mater. Process. Technol. 2008, 201, 716-719. [CrossRef]

16. Davies, G.; Zhen, S. Metallic foams: Their production, properties and applications. J. Mater. Sci. 1983, 18, 1899-1911. [CrossRef]

17. You, B.; Jiang, J.; Fan, S. Three-dimensional hierarchically porous all-carbon foams for supercapacitor. ACS Appl. Mater. Interfaces 2014, 6, 15302-15308. [CrossRef] [PubMed] 
18. Jacobs, L.J.M.; Kemmere, M.F.; Keurentjes, J.T.F. Sustainable polymer foaming using high pressure carbon dioxide: A review on fundamentals, processes and applications. Green Chem. 2008, 10, 731-738. [CrossRef]

19. Okolieocha, C.; Raps, D.; Subramaniam, K.; Altstädt, V. Microcellular to nanocellular polymer foams: Progress (2004-2015) and future directions-A review. Eur. Polym. J. 2015, 73, 500-519. [CrossRef]

20. Banhart, J. Aluminum foams: On the road to real applications. Mrs Bull. 2003, 28, 290-295. [CrossRef]

21. Raps, D.; Hossieny, N.; Park, C.B.; Altstädt, V. Past and present developments in polymer bead foams and bead foaming technology. Polymer 2015, 56, 5-19. [CrossRef]

22. Martini-Vvedensky, J.E.; Suh, N.P.; Waldman, F.A. Microcellular Closed Cell Foams and Their Method of Manufacture. U.S. Patent 44,736,65A, 25 September 1984.

23. Sauceau, M.; Fages, J.; Common, A.; Nikitine, C.; Rodier, E. New challenges in polymer foaming: A review of extrusion processes assisted by supercritical carbon dioxide. Prog. Polym. Sci. 2011, 36, 749-766. [CrossRef]

24. Chauvet, M.; Sauceau, M.; Fages, J. Extrusion assisted by supercritical $\mathrm{CO}_{2}$ : A review on its application to biopolymers. J. Supercrit. Fluids 2017, 120, 408-420. [CrossRef]

25. Farhan, S.; Wang, R.; Jiang, H.; Li, K.; Wang, C. A novel combination of simple foaming and freeze-drying processes for making carbon foam containing multiwalled carbon nanotubes. Ceram. Int. 2016, 42, 8980-8989. [CrossRef]

26. Dong, S.; Ji, X.; Yu, M.; Xie, Y.; Zhang, D.; He, X. Direct synthesis of interconnected porous carbon nanosheet/nickel foam composite for high-performance supercapacitors by microwave-assisted heating. J. Porous Mater. 2017, 25, 923-933. [CrossRef]

27. Rezvanpanah, E.; Ghaffarian Anbaran, S.R.; Maio, E.D. Carbon nanotubes in microwave foaming of thermoplastics. Carbon 2017, 125, 32-38. [CrossRef]

28. Ferrari-John, R.; Batchelor, A.; Katrib, J.; Dodds, C.; Kingman, S. Understanding selectivity in radio frequency and microwave sorting of porphyry copper ores. Int. J. Miner. Process. 2016, 155, 64-73. [CrossRef]

29. Jones, D.A.; Lelyveld, T.; Mavrofidis, S.; Kingman, S.; Miles, N. Microwave heating applications in environmental engineering-A review. Resour. Conserv. Recycl. 2002, 34, 75-90. [CrossRef]

30. Zhou, J.; Shi, C.; Mei, B.; Yuan, R.; Fu, Z. Research on the technology and the mechanical properties of the microwave processing of polymer. J. Mater. Process. Technol. 2003, 137, 156-158. [CrossRef]

31. Singh, R.P.; Heldman, D.R. Introduction to Food Engineering; Elsevier: Amsterdam, The Netherlands, 2001.

32. Razza, F.; Degli Innocenti, F.; Dobon, A.; Aliaga, C.; Sanchez, C.; Hortal, M. Environmental profile of a bio-based and biodegradable foamed packaging prototype in comparison with the current benchmark. J. Clean. Prod. 2015, 102, 493-500. [CrossRef]

33. Ahmad Zauzi, N.S.; Ariff, Z.M.; Khimi, S.R. Foamability of Natural Rubber via Microwave Assisted Foaming with Azodicarbonamide (ADC) as Blowing Agent. Mater. Today Proc. 2019, 17, 1001-1007. [CrossRef]

34. Xu, H.; Xu, P.; Wang, D.; Yang, Y.; Wang, X.; Wang, T.; An, W.; Xu, S.; Wang, Y.-Z. A dimensional stable hydrogel-born foam with enhanced mechanical and thermal insulation and fire-retarding properties via fast microwave foaming. Chem. Eng. J. 2020, 399, 125781. [CrossRef]

35. Wang, Y.; Ke, L.; Peng, Y.; Yang, Q.; Liu, Y.; Wu, Q.; Tang, Y.; Zhu, H.; Dai, L.; Zeng, Z.; et al. Ex-situ catalytic fast pyrolysis of soapstock for aromatic oil over microwave-driven HZSM-5@SiC ceramic foam. Chem. Eng. J. 2020, 402, 126239. [CrossRef]

36. Kang, Y.; Li, W.; Ma, T.; Huang, X.; Mo, Y.; Chu, Z.; Zhang, Z.; Feng, G. Microwave-constructed honeycomb architectures of h-BN/rGO nano-hybrids for efficient microwave conversion. Compos. Sci. Technol. 2019, 174, 184-193. [CrossRef]

37. Bilecka, I.; Niederberger, M. Microwave chemistry for inorganic nanomaterials synthesis. Nanoscale 2010, 2, 1358-1374. [CrossRef]

38. Chien, Y.-C. Field Study of in situ remediation of petroleum hydrocarbon contaminated soil on site using microwave energy. J. Hazard. Mater. 2012, 199, 457-461. [CrossRef] [PubMed]

39. Minay, E.; Veronesi, P.; Cannillo, V.; Leonelli, C.; Boccaccini, A. Control of pore size by metallic fibres in glass matrix composite foams produced by microwave heating. J. Eur. Ceram. Soc. 2004, 24, 3203-3208. [CrossRef]

40. Jimenez, G.D.; Monti, T.; Titman, J.J.; Hernandez-Montoya, V.; Kingman, S.; Binner, E. New insights into microwave pyrolysis of biomass: Preparation of carbon-based products from pecan nutshells and their application in wastewater treatment. J. Anal. Appl. Pyrolysis 2017, 124, 113-121. [CrossRef]

41. John, R.; Batchelor, A.; Ivanov, D.; Udoudo, O.; Jones, D.; Dodds, C.; Kingman, S. Understanding microwave induced sorting of porphyry copper ores. Miner. Eng. 2015, 84, 77-87. [CrossRef] 
42. Metaxas, A.A.; Meredith, R.J. Industrial Microwwave Heating; IET Peter Peregrinus Ltd.: London, UK, 1983.

43. Calles-Arriaga, C.A.; López-Hernández, J.; Hernández-Ordoñez, M.; Echavarría-Solís, R.A.; Ovando-Medina, V.M. Thermal characterization of microwave assisted foaming of expandable polystyrene. Ing. Investig. Tecnol. 2016, 17, 15-21. [CrossRef]

44. Hong, Y.; Fang, X.; Yao, D. Processing of composite polystyrene foam with a honeycomb structure. Polym. Eng. Sci. 2015, 55, 1494-1503. [CrossRef]

45. Wu, K.; Park, H.-S.; Willert-Porada, M. Pyrolysis of polyurethane by microwave hybrid heating for the processing of NiCr foams. J. Mater. Process. Technol. 2012, 212, 1481-1487. [CrossRef]

46. Peng, X.; Song, J.; Nesbitt, A.; Day, R. Microwave foaming of starch-based materials (II) thermo-mechanical performance. J.Cell. Plast. 2013, 49, 147-160. [CrossRef]

47. Choe, J.; Kim, M.; Kim, J. A microwave foaming method for fabricating glass fiber reinforced phenolic foam. Compos. Struct. 2016, 152, 239-246. [CrossRef]

48. Zhou, J.; Song, J.; Parker, R. Structure and properties of starch-based foams prepared by microwave heating from extruded pellets. Carbohydr. Polym. 2006, 63, 466-475. [CrossRef]

49. Chevali, V.; Kandare, E. 13 Rigid biofoam composites as eco-efficient construction materials. In Biopolymers and Biotech Admixtures for Eco-Efficient Construction Materials; Pacheco-Torgal, F., Ivanov, V., Karak, N., Jonkers, H., Eds.; Woodhead Publishing: Cambridge, UK, 2016; pp. 275-304. [CrossRef]

50. Obradovic, J.; Voutilainen, M.; Virtanen, P.; Lassila, L.; Fardim, P.J.M. Cellulose fibre-reinforced biofoam for structural applications. Materials 2017, 10, 619. [CrossRef]

51. López-Gil, A.; Silva-Bellucci, F.; Velasco, D.; Ardanuy, M.; Rodriguez-Perez, M. Cellular structure and mechanical properties of starch-based foamed blocks reinforced with natural fibers and produced by microwave heating. Ind. Crop. Prod. 2015, 66, 194-205. [CrossRef]

52. Song, S.A.; Oh, H.J.; Kim, B.G.; Kim, S.S. Novel foaming methods to fabricate activated carbon reinforced microcellular phenolic foams. Compos. Sci. Technol. 2013, 76, 45-51. [CrossRef]

53. Ranjan, S.; Dasgupta, N.; Rajendran, B.; Avadhani, G.S.; Ramalingam, C.; Kumar, A. Microwave-irradiation-assisted hybrid chemical approach for titanium dioxide nanoparticle synthesis: Microbial and cytotoxicological evaluation. Environ. Sci. Pollut. Res. 2016, 23, 12287-12302. [CrossRef] [PubMed]

54. Lamiel, C.; Kumar, D.R.; Shim, J.-J. Microwave-assisted binder-free synthesis of 3D Ni-Co-Mn oxide nanoflakes@ Ni foam electrode for supercapacitor applications. Chem. Eng. J. 2017, 316, 1091-1102. [CrossRef]

55. Huang, Z.; Zhang, H.; Chen, Y.; Wang, W.; Chen, Y.; Zhong, Y. Microwave-assisted synthesis of functionalized graphene on $\mathrm{Ni}$ foam as electrodes for supercapacitor application. Electrochim. Acta 2013, 108, 421-428. [CrossRef]

56. Ou, X.; Xu, S.; Warnett, J.M.; Holmes, S.M.; Zaheer, A.; Garforth, A.A.; Williams, M.A.; Jiao, Y.; Fan, X. Creating hierarchies promptly: Microwave-accelerated synthesis of ZSM-5 zeolites on macrocellular silicon carbide (SiC) foams. Chem. Eng. J. 2017, 312, 1-9. [CrossRef]

57. Demitri, C.; Giuri, A.; Raucci, M.G.; Giugliano, D.; Madaghiele, M.; Sannino, A.; Ambrosio, L. Preparation and characterization of cellulose-based foams via microwave curing. Interface Focus 2014, 4, 20130053. [CrossRef]

58. Thomas-Hillman, I.; Laybourn, A.; Dodds, C.; Kingman, S.W. Realising the environmental benefits of metal-organic frameworks: Recent advances in microwave synthesis. J. Mater. Chem. A. 2018, 6, 11564-11581. [CrossRef]

59. Canencia, F.; Darder, M.; Aranda, P.; Fernandes, F.M.; Gouveia, R.F.; Ruiz-Hitzky, E. Conducting macroporous carbon foams derived from microwave-generated caramel/silica gel intermediates. J. Mater. Sci. 2017, 52, 11269-11281. [CrossRef]

60. Haq, E.U.; Padmanabhan, S.K.; Licciulli, A. Microwave synthesis of thermal insulating foams from coal derived bottom ash. Fuel Process. Technol. 2015, 130, 263-267. [CrossRef]

61. Peyda, S.; Morshedian, J.; Karbalaei-Bagher, M.; Baharvand, H.; Khorasani, M.T. A novel technique in the foaming process of EPDM/PP via microwave radiation: The effect of blend compatibilization and additive encapsulation. RSC Adv. 2016, 6, 81400-81407. [CrossRef]

62. van der Sman, R.G.M.; Bows, J.R. Critical factors in microwave expansion of starchy snacks. J. Food Eng. 2017, 211, 69-84. [CrossRef]

63. Hardy, Z.; Jideani, V.A. Foam-mat drying technology: A review. Crit. Rev. Food Sci. Nutr. 2017, 57, $2560-2572$. [CrossRef] 
64. Peng, X.; Song, J.; Nesbitt, A.; Day, R. Microwave foaming of starch-based materials (I) dielectric performance. J. Cell. Plast. 2013, 49, 245-258. [CrossRef]

65. Kraus, S.; Schuchmann, H.P.; Gaukel, V. Factors Influencing the Microwave-Induced Expansion of Starch-Based Extruded Pellets under Vacuum. J. Food Process. Eng. 2014, 37, 264-272. [CrossRef]

66. Kraus, S.; Sólyom, K.; Schuchmann, H.P.; Gaukel, V. Drying Kinetics and Expansion of Non-predried Extruded Starch-Based Pellets during Microwave Vacuum Processing. J. Food Process. Eng. 2013, 36, 763-773. [CrossRef]

67. Chanvrier, H.; Chaunier, L.; Della Valle, G.; Lourdin, D. Flow and foam properties of extruded maize flour and its biopolymer blends expanded by microwave. Food Res. Int. 2015, 76, 567-575. [CrossRef] [PubMed]

68. Song, S.A.; Chung, Y.S.; Kim, S.S. The mechanical and thermal characteristics of phenolic foams reinforced with carbon nanoparticles. Compos. Sci. Technol. 2014, 103, 85-93. [CrossRef]

69. Prociak, A.; Owski, S.; Bąk, S. Thermoplastic polyurethane foamed under microwave irradiation. Polimery 2012, 57, 786-790. [CrossRef]

70. Hong, Y.; Fang, X.; Yao, D. Microwave processing of syntactic foam from an expandable thermoset/thermoplastic mixture. Polym. Eng. Sci. 2015, 55, 1818-1828. [CrossRef]

71. Demitri, C.; Giuri, A.; De Benedictis, V.M.; Raucci, M.G.; Giugliano, D.; Sannino, A.; Ambrosio, L. Microwave-induced porosity and bioactivation of chitosan-PEGDA scaffolds: Morphology, mechanical properties and osteogenic differentiation. J. Tissue Eng. Regen. Med. 2017, 11, 86-98. [CrossRef]

72. Yamamoto, T.; Kobashi, M.; Kanetake, N. Production of the Al3Ti foam by microwave heating. In ICAA13 Pittsburgh; Springer: Berlin/Heidelberg, Germany, 2012; pp. 1043-1047.

73. Ruiz-Trejo, E.; Azad, A.K.; Irvine, J.T. A 60-second microwave-assisted synthesis of nickel foam and its application to the impregnation of porous scaffolds. J. Electrochem. Soc. 2015, 162, F273-F279. [CrossRef]

74. Paul, R.; Voevodin, A.A.; Zemlyanov, D.; Roy, A.K.; Fisher, T.S. Microwave-Assisted Surface Synthesis of a Boron-Carbon-Nitrogen Foam and its Desorption Enthalpy. Adv. Funct. Mater. 2012, 22, 3682-3690. [CrossRef]

75. Kolbitsch, C.; Link, M.; Petutschnigg, A.; Wieland, S.; Tondi, G. Microwave produced tannin-furanic foams. J. Mater. Sci. Res. 2012, 1, 84. [CrossRef]

76. Moraru, C.; Kokini, J. Nucleation and expansion during extrusion and microwave heating of cereal foods. Compr. Rev. Food Sci. Food Saf. 2003, 2, 147-165. [CrossRef]

77. CellMat. Microwave Foaming of Starch. Bioplastic Cellular Materials. Available online: http://cellmat.es/ bioplastic-cellular-materials/ (accessed on 1 October 2020).

78. Lee, G.H.; Park, B.K.; Lee, W.I. Microstructure and property characterization of flexible syntactic foam for insulation material via mold casting. Int. J. Precis. Eng. Manuf. Green Technol. 2017, 4, 169-176. [CrossRef]

79. Yu, Q.; Zhao, Y.; Dong, A.; Li, Y. Preparation and Properties of C/C Hollow Spheres and the Energy Absorption Capacity of the Corresponding Aluminum Syntactic Foams. Materials 2018, 11, 997. [CrossRef]

80. Yu, Q.; Zhao, Y.; Dong, A.; Li, Y. Mechanical properties of EPS filled syntactic foams prepared by VARTM. Compos. Part B Eng. 2018, 136, 126-134. [CrossRef]

81. Park, S.-J.; Lee, H.-Y.; Lee, J.-R. Curing and thermal properties of a microwave radiation-curable epoxy/latent catalyst system. J. Ind. Eng. Chem. 2005, 11, 726-731.

82. Jee, C.; Guo, Z.; Evans, J.; Özgüven, N. Preparation of high porosity metal foams. Metall. Mater. Trans. B 2000, 31, 1345-1352. [CrossRef]

83. Peng, H.; Fan, Z.; Evans, J.; Busfield, J. Microstructure of ceramic foams. J. Eur. Ceram. Soc. 2000, 20, 807-813. [CrossRef]

84. Chan, T.V.C.T.; Reader, H.C. Understanding Microwave Heating Cavities; Artech House Publishers: Norwood, MA, USA, 2000.

85. Arimi, J.; Duggan, E.; O’Riordan, E.; O'Sullivan, M.; Lyng, J. Microwave expansion of imitation cheese containing resistant starch. J. Food Eng. 2008, 88, 254-262. [CrossRef]

86. Sjöqvist, M.; Gatenholm, P. Effect of water content in potato amylopectin starch on microwave foaming process. J. Polym. Environ. 2007, 15, 43. [CrossRef]

87. Boischot, C.; Moraru, C.; Kokini, J. Factors that influence the microwave expansion of glassy amylopectin extrudates. Cereal Chem. 2003, 80, 56. [CrossRef]

88. Gibson, L.J.; Ashby, M.F. Cellular Solids: Structure and Properties; Cambridge University Press: Cambridge, UK, 1999. 
89. Song, S.A.; Lee, Y.; Kim, Y.S.; Kim, S.S. Mechanical and thermal properties of carbon foam derived from phenolic foam reinforced with composite particles. Compos. Struct. 2017, 173, 1-8. [CrossRef]

90. Prosperetti, A. A generalization of the Rayleigh-Plesset equation of bubble dynamics. Phys. Fluids 1982, 25, 409-410. [CrossRef]

91. Tong, C.; Lund, D. Microwave heating of baked dough products with simultaneous heat and moisture transfer. J. Food Eng. 1993, 19, 319-339. [CrossRef]

92. Khraisheh, M.; Cooper, T.; Magee, T. Microwave and air drying I. Fundamental considerations and assumptions for the simplified thermal calculations of volumetric power absorption. J. Food Eng. 1997, 33, 207-219. [CrossRef]

93. Mishra, R.R.; Sharma, A.K. Microwave-material interaction phenomena: Heating mechanisms, challenges and opportunities in material processing. Compos. Part A Appl. Sci. Manuf. 2016, 81, 78-97. [CrossRef]

94. Sait, H.H.; Salema, A.A. Microwave dielectric characterization of Saudi Arabian date palm biomass during pyrolysis and at industrial frequencies. Fuel 2015, 161, 239-247. [CrossRef]

95. Lin, H.; Luo, H.; Huang, W.; Zhang, X.; Yao, G. Diffusion bonding in fabrication of aluminum foam sandwich panels. J. Mater. Process. Technol. 2016, 230, 35-41. [CrossRef]

96. Chang, K.; Gao, J.-T.; Wang, Z.; Guo, Z.-C. Manufacturing 3-D open-cell aluminum foam via infiltration casting in a super-gravity field. J. Mater. Process. Technol. 2018, 252, 705-710. [CrossRef]

97. Lara-Rodriguez, G.A.; Figueroa, I.A.; Suarez, M.A.; Novelo-Peralta, O.; Alfonso, I.; Goodall, R. A replication-casting device for manufacturing open-cell Mg foams. J. Mater. Process. Technol. 2017, 243, 16-22. [CrossRef]

98. Zhu, W.; Hu, N.; Wei, Q.; Zhang, L.; Li, H.; Luo, J.; Lin, C.-T.; Ma, L.; Zhou, K.; Yu, Z. Carbon nanotube-Cu foam hybrid reinforcements in composite phase change materials with enhanced thermal conductivity. Mater. Des. 2019, 172, 107709. [CrossRef]

99. Li, Z.; Xu, J.; Sun, D.; Lin, T.; Huang, F. Nanoporous Carbon Foam for Water and Air Purification. ACS Appl. Nano Mater. 2020, 3, 1564-1570. [CrossRef]

100. Menéndez, J.; Arenillas, A.; Fidalgo, B.; Fernández, Y.; Zubizarreta, L.; Calvo, E.G.; Bermúdez, J.M. Microwave heating processes involving carbon materials. Fuel Process. Technol. 2010, 91, 1-8. [CrossRef]

101. Zubair, M.; Shehzad, F.; Al-Harthi, M.A. Impact of modified graphene and microwave irradiation on thermal stability and degradation mechanism of poly (styrene-co-methyl meth acrylate). Thermochim. Acta 2016, 633, 48-55. [CrossRef]

Publisher's Note: MDPI stays neutral with regard to jurisdictional claims in published maps and institutional affiliations.

(C) 2020 by the authors. Licensee MDPI, Basel, Switzerland. This article is an open access article distributed under the terms and conditions of the Creative Commons Attribution (CC BY) license (http://creativecommons.org/licenses/by/4.0/). 